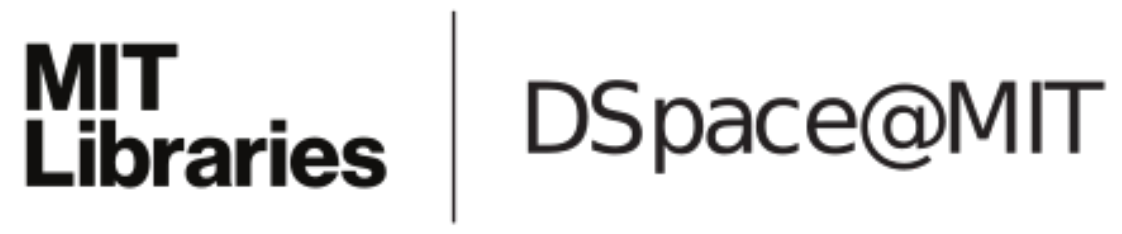

\author{
MIT Open Access Articles
}

Household Debt Revaluation and the Real Economy: Evidence from a Foreign Currency Debt Crisis

The MIT Faculty has made this article openly available. Please share how this access benefits you. Your story matters.

As Published: 10.1257/AER.20181585

Publisher: American Economic Association

Persistent URL: https://hdl.handle.net/1721.1/135262

Version: Final published version: final published article, as it appeared in a journal, conference proceedings, or other formally published context

Terms of Use: Article is made available in accordance with the publisher's policy and may be subject to US copyright law. Please refer to the publisher's site for terms of use. 


\title{
Household Debt Revaluation and the Real Economy: Evidence from a Foreign Currency Debt Crisis
}

\author{
By EMIL VERNER AND GYŐZŐ GYÖNGYÖSI*
}

\begin{abstract}
We examine the consequences of a sudden increase in household debt burdens by exploiting variation in exposure to household foreign currency debt during Hungary's late-2008 currency crisis. The revaluation of debt burdens causes higher default rates and a collapse in spending. These responses lead to a worse local recession, driven by a decline in local demand, and negative spillover effects on nearby borrowers without foreign currency debt. The estimates translate into an output multiplier on higher debt service of 1.67. The impact of debt revaluation is particularly severe when foreign currency debt is concentrated on household, rather than firm, balance sheets. (JEL E21, E32, F34, G51)
\end{abstract}

Rapid credit expansions are often followed by severe recessions..$^{1}$ One explanation for this pattern is that a high burden of debt itself depresses the economy. The contractionary effects of debt can be especially severe when debt is denominated in foreign currency, as a depreciation against the funding currency leads to debt revaluation that can impair private sector balance sheets. While foreign currency financing by firms has received considerable attention, households also often borrow in foreign currency. Throughout emerging Europe before the 2008 financial crisis, for example, rapid growth in foreign currency household credit was followed by large debt revaluations and severe household financial distress. These dynamics raise several questions. What role does household foreign currency debt revaluation play in exacerbating economic crises? Does it matter whether it is households or

\footnotetext{
*Verner: Sloan School of Management, Massachusetts Institute of Technology (email: everner@mit.edu); Gyöngyösi: Kiel Institute for the World Economy, and National Bank of Hungary (email: gyozo.gyoengyoesi@ifwkiel.de). Emi Nakamura was the coeditor for this article. This research received financial support from the Alfred P. Sloan Foundation through the NBER Household Finance small grant program. We are extremely grateful to Atif Mian, Mark Aguiar, Adrien Matray, Motohiro Yogo, and Wei Xiong for valuable guidance and encouragement. For helpful comments, we thank three anonymous referees, Adrien Auclert, Tamás Briglevics, Markus Brunnermeier, Will Dobbie, Sergio de Ferra, Bo Honoré, Oleg Itskhoki, Nobu Kiyotaki, Stefan Lewellen, Ben Moll, Dmitry Mukhin, Karsten Müller, Mikkel Plagborg-Møller, Dániel Palotai, Jonathan Parker, Judit Rariga, Federico Ravenna, Michala Riis-Vestergaard, Eyno Rots, Jesse Schreger, Chris Sims, Amir Sufi, Adrien Verdelhan, Gianluca Violante, Ben Young, and seminar participants at various conferences and seminars. We thank Ádám Szeidl for sharing CEU's establishment location dataset, Elisabeth Beckman and the Austrian Central Bank for sharing the Euro Survey data, and János Köllő and MTA KRTK Databank for sharing the T-Star data. Réka Zempléni provided excellent research assistance. The views in this paper are solely those of the authors and do not necessarily reflect the views of the National Bank of Hungary.

Go to https://doi.org/10.1257/aer.20181585 to visit the article page for additional materials and author disclosure statements.

${ }^{1}$ Several studies show that rapid expansions in debt, especially household debt, predict financial crises and more severe economic downturns (e.g., Jordà, Schularick, and Taylor 2014; Mian, Sufi, and Verner 2017).
} 
firms who borrow in foreign currency? More broadly, how does the economy adjust to a sudden increase in household debt burdens?

In this paper, we examine how a revaluation of household foreign currency debt affects the real economy in a currency crisis. Focusing on the case of Hungary, we exploit individual and spatial variation in households' exposure to foreign currency debt during the sharp depreciation of the Hungarian forint starting in late 2008. We provide three main results on the effects of household debt revaluation. First, the household debt revaluation causes a significant increase in household financial distress and a worse local recession, driven by a decline in local demand. Second, the debt revaluation has negative spillovers on nearby households, including households without foreign currency debt. Third, the contractionary effects of debt revaluation on the local economy are more severe when foreign currency debt is concentrated in the household sector, rather than the corporate sector.

Hungary provides an ideal setting to study the consequences of household foreign currency debt revaluation for two reasons. First, in 2008, 69 percent of household debt was denominated in foreign currency, primarily Swiss franc. Second, Hungary experienced a sharp depreciation of over 30 percent in late 2008. The depreciation was largely unexpected and was driven by factors unrelated to the household sector in Hungary, including a strong appreciation of the Swiss franc. This combination led to a sudden increase in household debt to GDP of over 6 percentage points. While we focus on Hungary, foreign currency retail lending, especially to households, was widespread throughout emerging Europe in the 2000s, leading to "unprecedented" levels of currency mismatch (Ranciere, Tornell, and Vamvakidis 2010).

We use administrative household credit registry data from Hungary to construct a new dataset on household debt and default at the individual and regional level. We match these household credit data at the regional level with measures of household spending, unemployment, and house prices. Moreover, we combine these data with firm-level census and credit registry data that include information on employment, investment, export status, and firm debt by currency. Our data, therefore, provide a complete picture of private nonfinancial foreign currency borrowing.

Our empirical approach exploits variation in exposure to foreign currency debt across individuals and regions around the large depreciation of the Hungarian forint. Variation is primarily driven by the timing of borrowing due to changes in the availability of government-subsidized local currency loans. Areas with a greater initial depth of domestic banks experienced more domestic currency lending at first. After the subsidy was curtailed, foreign banks, the main foreign currency lenders, greatly expanded their branch network. This led to a catch up in indebtedness and higher foreign currency debt exposure in initially underserved regions.

At the individual level, various survey datasets reveal that foreign and local currency borrowers are broadly similar on observable dimensions, with foreign currency borrowers having slightly higher income and education. At the regional level, areas with a higher share of household debt in foreign currency have similar debt-to-income, loan-to-value ratios, export intensity, and corporate foreign currency debt. However, these regions have lower population, income, and education, as well as higher precrisis default rates. These patterns suggest that foreign banks lending in foreign currency entered lower income areas previously underserved by domestic banks. In our empirical analysis, we explicitly account for these differences in observable characteristics. 
We first show that household debt revaluation leads to a strong increase in household defaults and a decline in durable spending. Using data across 2,538 local areas (municipalities), we find that a 1 percentage point increase in debt-to-income induced by the debt revaluation leads to a 0.15 percentage point increase in default rates and a 1.3 percent decline in durable spending. Household foreign currency debt explains 71 percent of the rise in overall default rates, abstracting from aggregate equilibrium effects. The strong default and spending response to debt revaluation is consistent with models with incomplete markets where households have unhedged foreign currency debt positions.

Next, we investigate how the household debt revaluation affects local labor markets. Standard theoretical models have different predictions about how a debt revaluation affects real activity. In neoclassical open economy models with flexible prices, debt revaluation lowers consumption but increases employment and output, as households boost labor supply. In contrast, if there are frictions such as nominal rigidities, the debt-induced decline in consumption translates into a decline in employment and output.

We find that regions with greater exposure to household foreign currency debt experience a significant and persistent rise in unemployment after the depreciation. A region where all debt is in foreign currency experiences a 1.65 percentage point rise in unemployment, relative to a region with only domestic currency debt. In terms of magnitudes, the estimates imply that a $\$ 29,000$ (2008 PPP) increase in annual debt service destroys one job-year. This "debt service-per-job" estimate translates into an estimated peak output multiplier of 1.67 two years after the initial depreciation.

Why does the household debt revaluation lead to persistently higher local unemployment? Exploiting firm-level census data, we show that the rise in unemployment is driven by employment losses at nonexporting firms and firms in the nontradable sector. By contrast, exporting firms are unaffected. These effects are consistent with the debt revaluation depressing real activity through a decline in local household demand. We also find evidence of limited adjustment through wage declines, migration, or reallocation to exporting firms, consistent with models containing frictions such as nominal and real rigidities. In addition, regions with more exposure to household foreign currency debt experience a persistent relative decline in house prices after the depreciation. The amplification through house price declines is broadly consistent with models of pecuniary externalities from collateralized foreign currency borrowing (e.g., Mendoza 2010, Korinek 2011).

The rise in unemployment and decline in house prices likely affects all households in a local economy, including those that did not borrow in foreign currency. An important questions is thus whether the shock propagates across households. Using loan-level data, we find direct evidence that foreign currency debt has negative spillover effects on other borrowers. A borrower living in regions where other households borrowed heavily in foreign currency is more likely to default, conditional on the borrower's own foreign currency debt position. The spillovers even affect borrowers with only domestic currency debt. The negative spillover effect is consistent with theories where debt has negative demand and pecuniary externalities (e.g., Farhi and Werning 2016, Korinek and Simsek 2016). 
In the final part of the paper, we compare the consequences of household foreign currency debt and a traditional channel of emerging market crises: firm foreign currency indebtedness. In contrast to households, firms with foreign currency debt are strongly positively selected. Firms with foreign currency debt are larger, more productive, faster growing, and more likely to be exporters. Moreover, firm foreign currency debt is primarily denominated in euro, the main invoicing currency for exports, while household foreign currency debt is almost exclusively in Swiss franc. After the depreciation, firms with foreign currency exposure cut back sharply on investment, consistent with a negative balance sheet effect. However, at the same time, these firms see stronger sales and employment growth during the crisis, as they use foreign currency financing to grow more quickly (Salomao and Varela 2016). As a result, the impact of debt revaluation on the local economy is particularly severe when foreign currency debt is concentrated in the household sector.

This paper contributes to the international finance literature on foreign currency debt and currency crises. This literature has focused on firm, bank, and government foreign currency indebtedness..$^{2}$ To our knowledge, our paper is the first to analyze the effects of household foreign currency debt, despite the prevalence of household foreign currency debt throughout emerging Europe in the 2000s and numerous previous financial crises. In addition, whereas the previous literature has documented a foreign currency balance-sheet effect at the firm level, we show that household foreign currency exposure has local aggregate effects, including negative spillover effects on other borrowers. We thus also provide empirical evidence on the classic Transfer Problem, which asks how the economy adjusts to an increase in external debt burdens (Keynes 1929).

This paper also contributes to a growing literature on household leverage and business cycles. A long tradition in macroeconomics, going back to Fisher's (1933) debt-deflation hypothesis, emphasizes that a combination of high household debt, deleveraging, and asset price declines can exacerbate output declines in a recession. ${ }^{3}$ To examine the role of debt, the existing literature has primarily focused on the consequences of expansions in household debt prior to crises. $\rrbracket^{4}$ However, expansions in household debt are often part of a broader cycle in real activity and financial conditions, which makes it difficult to disentangle whether and why higher debt itself causes more severe recessions. We contribute to this literature by tracing the effect of a shock directly to household debt, which allows us to estimate the direct effects of higher household debt, holding fixed other cyclical factors, capturing what Auclert (2016) refers to as the "Fisher channel" of nominal debt revaluation.

\footnotetext{
${ }^{2}$ Eichengreen and Hausman (2005) provides an overview of foreign currency financing in emerging markets. A number of studies analyze the causes and consequences of firm foreign currency exposures in emerging market crises (e.g. Krugman 1999, Caballero and Krishnamurthy 2003). Some firm-level studies find that firm foreign currency debt depresses investment and leads to higher firm exit rates (e.g., Aguiar 2005; Kim, Tesar, and Zhang 2015; Du and Schreger 2015), but other studies suggest that many firms with FC debt are positively selected and often naturally hedged (e.g., Bleakley and Cowan 2008). Cross-country studies find that the country-level FC debt exposure increases the probability and severity of a sudden stop crisis (e.g., Calvo, Izquierdo, and Mejía 2008), but the use of aggregate data makes it difficult to disentangle the role of household, firm, and bank balance sheet effects, as well as other country-level shocks and policy responses.

${ }^{3}$ See, for example, Mishkin (1978); Mian, Rao, and Sufi (2013); and Eggertsson and Krugman (2012).

${ }^{4}$ Relevant studies include Dynan (2012); Mian and Sufi (2014a); Jordà, Schularick, and Taylor (2014); Mian, Sufi, and Verner (2017, 2020); and Di Maggio and Kermani (2017).
} 
Our analysis, therefore, also connects with recent studies showing that borrowers who experience debt payment reductions have a lower probability of default and use additional funds to increase spending on durables (e.g., Agarwal et al. 2017, Di Maggio et al. 2017, Ganong and Noel 2019). Relative to these studies, we examine a large shock to debt, with variation across individuals and regions. This allows us to focus on local equilibrium effects, estimate a multiplier on higher debt service, and show that foreign currency financing has negative spillover effects. Auclert, Dobbie, and Goldsmith-Pinkham (2019) also explores local aggregate implications of debt and finds that US states with more generous bankruptcy exemptions experienced smaller employment declines in the Great Recession.

The remainder of the paper is structured as follows. Section I discusses the background on the foreign currency debt crisis in Hungary. Section II describes the data. Section III discusses the theoretical framework and empirical methodology. Section IV presents the main results. Sections V and VI provide evidence on the mechanisms and spillover effects of FC debt. Section VII compares the impact of household and firm foreign currency exposures, and Section VIII concludes.

\section{The Hungarian Foreign Currency Debt Crisis}

Foreign currency (FC) retail lending was widespread throughout Europe prior to the 2008 financial crisis, especially in new EU member states..$^{5}$ Hungary experienced a particularly rapid expansion in household credit in both domestic and foreign currency. Figure 1 shows that between 2000 and 2008 household debt to GDP increased by 28 percentage points. The expansion was financed mainly by two categories of loans: government-subsidized local currency (LC) housing loans and unsubsidized FC loans. In September 2008, 69 percent of outstanding housing debt was denominated in foreign currency, primarily Swiss franc. This directly exposed household balance sheets to the large depreciation of the Hungarian forint in the Global Financial Crisis.

Household lending in Hungary was initially spurred by a government housing program that provided interest rate subsidies on LC mortgages. The subsidy was introduced in 2000 and fixed nominal interest rates for borrowers at levels similar to euro interest rates ( 4 to 6 percent). ${ }^{6}$ Subsidized LC lending was driven primarily by domestic mortgage banks, as these banks had a tax advantage in originating subsidized loans (Rózsavölgyi and Kovács 2005). Since average retail banking density

\footnotetext{
${ }^{5}$ For example, during the 2000s, a large proportion of housing and consumption loans were denominated in FC in the following countries: Austria, Iceland, Estonia, Latvia, Lithuania, Poland, Hungary, Slovenia, Croatia, Serbia, Bosnia and Herzegovina, Bulgaria, Romania, and Ukraine. Household lending in Swiss franc and yen was also common in Denmark, Greece, Spain, and the United Kingdom. Household foreign currency debt also played a role in previous currency crises in both advanced and emerging markets. In Australia during the early 1980s, a substantial amount of bank lending to consumers and farmers was denominated in Swiss franc and Japanese yen, leading to widespread defaults and bankruptcies following the depreciation of the Australian dollar starting in 1986. Households in Sweden and Finland also had exposure to foreign currency debt during the Nordic crisis of the early 1990s. As another example, prior to Argentina's crisis and devaluation in 2002, 80 percent of mortgages were denominated in US dollars (IMF 2003).

${ }^{6}$ Unsubsidized local currency loans with market interest rates comprised 7 percent of local currency housing loans in September 2008. The typical subsidized mortgage loan had a 15- to 20-year maturity with a fixed rate for the first five years and capped interest rates paid by households at 6 percent. This placed all interest rate risk on the government budget.
} 


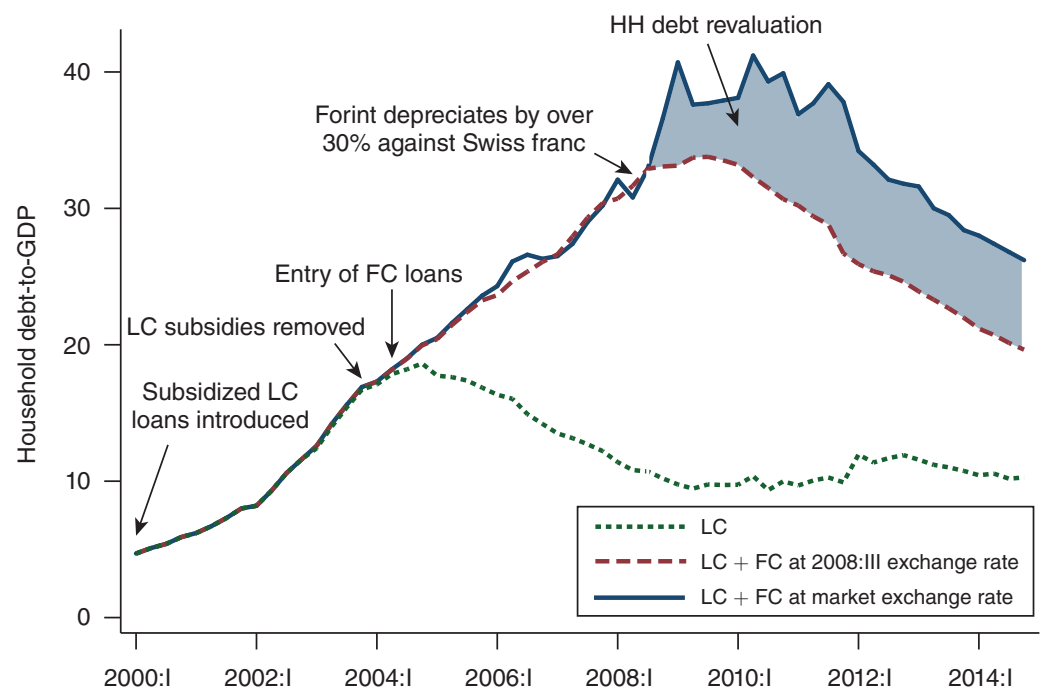

Figure 1. Household Debt Revaluation

Note: This figure shows the expansion in total household debt-to-GDP by currency and the revaluation of foreign currency debt induced by the depreciation of the Hungarian forint.

Sources: Data are from BIS (2019) and MNB (2019)

following the transition from communism was low, subsidized LC housing credit growth was strongest in regions with a higher historical density of domestic banks.

The domestic currency mortgage subsidy program placed a significant burden on public finances, and subsidies on new loans were unexpectedly cut back in early 2004. The increased cost of LC loans led foreign banks to enter the retail lending market and compete with domestic banks by offering low-interest-rate FC housing loans. Figure 1 shows that the FC credit expansion began in the middle of 2004. Foreign banks competing for market share expanded FC credit aggressively, especially to areas with lower subsidized debt (Banai, Király, and Nagy 2011). Interest rates on Swiss franc and euro loans averaged 4 to 6 percent, which implied savings of about 5 percentage points relative to domestic currency loans at market rates, holding the exchange rate constant. The increased foreign currency debt exposure was almost entirely unhedged, as households income and assets in foreign currency were negligible.

The foreign currency credit expansion occurred during a stable exchange rate environment. Figure 2 shows that the forint exchange rate remained stable against the euro and Swiss franc up to October 2008. Prior to February 2008, the National Bank of Hungary (MNB) maintained a crawling band with respect to the euro. Meanwhile, the Swiss franc was quasi-fixed against the euro.7 This stability led market participants to believe that a large depreciation was unlikely. In a survey from November 2008, Pellényi and Bilek (2009) finds that 87 percent of

\footnotetext{
${ }^{7}$ Ilzetzki, Reinhart, and Rogoff (2019) classifies the forint regime as a de facto \pm 5 percent band around the euro and the Swiss franc regime $\mathrm{a} \pm 2$ percent band around the euro.
} 


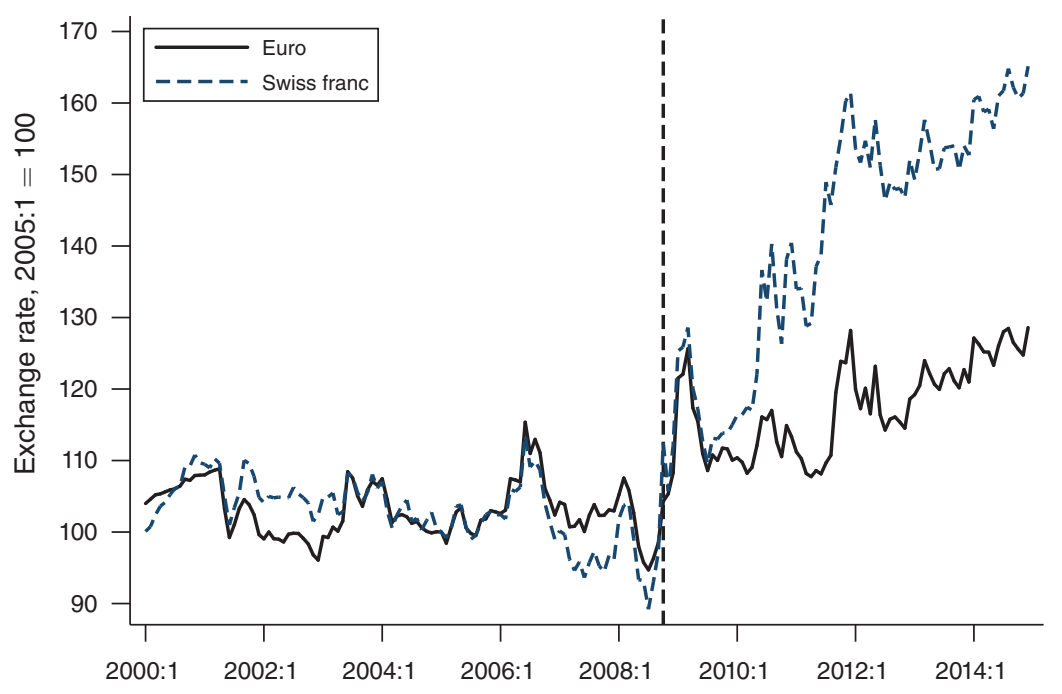

Figure 2. Exchange Rate Dynamics

Notes: This figure shows the evolution of the forint-euro and forint-Swiss franc exchange rates (IFS 2016). The de facto \pm 5 percent crawling band target maintained until February 2008 was followed by a series of depreciations starting in October 2008. The vertical dashed line represents September 2008, the month prior to the forint depreciation.

respondents with an FC loan did not expect exchange rate volatility at the late 2008 level. Online Appendix Figure A.1 shows that Consensus Forecast also predicted a stable forint-euro exchange rate in mid-2008. Further, Hungary joined the European Union in May 2004 and initially targeted adopting the euro in 2007. Survey evidence shows that the expectation of adopting the euro boosted FC loan demand (Fidrmuc, Hake, and Stix 2013).

Following a decade of exchange rate stability, the forint depreciated by 27.5 percent against the euro and 32.3 percent against the Swiss franc between September 2008 and March 2009. The initial depreciation was caused by the general flight to safety away from emerging markets and was exacerbated by investor concerns about the Hungarian government's large external financing needs..$^{8}$ The forint weakened further against the Swiss franc in 2010 and 2011, as the Swiss franc appreciated during the eurozone crisis. From the perspective of this study, the depreciation provides a promising shock, as it was not caused by distress in household credit markets. This allays concerns of reverse causality from household distress to exchange rate depreciation.

Figure 1 compares the value of aggregate household debt at market exchange rates relative to a counterfactual where the exchange rate had remained at its September 2008 value. The large depreciation revalued household debt burdens by 6 percent of GDP by mid-2010.9 The impact of the depreciation on debt service was reinforced

\footnotetext{
${ }^{8}$ Hungary received a \$25 billion IMF loan to meet the government's external financing gap in October 2008.

${ }^{9}$ Starting in the second half of 2011, the newly elected conservative government implemented a variety of policies to alleviate the sharp rise in monthly installments. These efforts culminated in the conversion of the entire stock of foreign currency housing loans into domestic currency in November 2014. Our analysis focuses primarily on the
} 
by interest rates increases on variable rate unsubsidized loans. Rising interest rates have an analogous effect on debt service as an additional depreciation and account for approximately 25 percent of the increase in debt service payments in the crisis (Szigel 2012). ${ }^{10}$ For example, from September 2008 to the end of 2011, debt service for the average FC housing loan rose by 77 percent, with 58 percentage points of the increase being driven by the exchange rate depreciation and the remainder by higher interest rates.

The depreciation was associated with a current account reversal and a severe recession. Online Appendix Figure A.2 presents the dynamics of other key aggregate variables. Private consumption fell more than output and had yet to recover to its precrisis level by the end of 2014. Beyond household FC exposure, high government debt and fiscal adjustment contributed to the severity of the recession, along with the sharp decline in global trade (IMF 2011). While the banking sector entered the crisis with healthy capital positions and limited currency mismatch, reduced access to international liquidity and rising nonperforming loans weighed negatively on credit conditions.

\section{Data and Summary Statistics}

We construct a new region-level dataset with information on household debt by currency and loan type, default, spending, unemployment rate, house prices, wages, and demographic variables. The primary level of aggregation in our data is a settlement (municipality). From the 3,152 settlements in Hungary, we construct a balanced panel covering 2,538 settlements for which our main outcome and control variables are nonmissing. The average population in our sample of settlements is 3,890 in 2007, and the sample covers 98.2 percent of the total population. We match this regional dataset with firm-level census data on employment, exports, balance-sheet information, and bank credit. For the analysis of individual defaults and local spillovers in Section VI, we also use the underlying loan and individual-level credit registry data. This section summarizes the key features of the data. Online Appendix Section B provides further details on the data sources and variable definitions.

\section{A. Household Credit Registry}

The Hungarian Household Central Credit Information System (Household Credit Registry) contains all loans extended by all credit institutions to individuals outstanding on or after April 2012 (MNB 2016c). The credit registry records information on the loan type, loan amount, date of origination, maturity, monthly payments, default status, and currency. ${ }^{11}$ The household credit registry also reports the borrower's settlement of residence. The credit registry, however, does not report

period between 2008 and 2012, prior to when these policies were implemented. See Gyöngyösi and Verner (2019) for an analysis of the political economy consequences of the household FC debt crisis.

${ }^{10}$ Interest rate increases primarily affected foreign currency loans, as interest rates on subsidized domestic currency mortgages were capped. Variable rate loans originated by banks operating in Hungary generally did not specify an underlying benchmark and spread. This allowed banks to unilaterally increase interest rates relative to Swiss franc benchmark rates during the crisis, a practice that was ruled unlawful in 2014.

${ }^{11}$ The household credit registry was preceded by a negative registry that contained information on default. Prior to 2010, the negative registry contains information on the most recent default. This allows us to extend default 
loan-to-value (LTV) ratios, so we estimate settlement LTV ratios using bank-level information on the LTV of new originations (MNB 2018a).

In order to measure a settlement's FC debt exposure prior to the 2008 forint depreciation, we reconstitute the credit registry back to 2000. Specifically, we use an annuity model and detailed interest rate data (MNB 2016a) to estimate monthly payments and outstanding debt prior to 2012 for all loans in the credit registry. We then rescale local debt measures to match the aggregate Financial Accounts by currency. The unscaled credit registry accounts for 80.5 percent of aggregate housing debt in the Financial Accounts in September 2008. In online Appendix Section B we also show that the annuity model also performs well at the loan level.

Loans that are terminated (repaid or refinanced) before 2012 but were outstanding in September 2008 present a potential measurement error problem for the estimation of a settlement's FC debt exposure. This primarily affects foreign currency loans, as, in the fall of 2011, the Hungarian government implemented an Early Repayment Program (ERP) that retired 21 percent of outstanding foreign currency debt. Accounting for the ERP raises the coverage of the credit registry in 2008 from 80.5 percent to 96 percent of aggregate housing debt.

In online Appendix Section B, we show that the main results in this paper are robust to three separate adjustments that proxy for debt prepaid in the ERP. The first adjustment uses a separate dataset on the universe of loans for three anonymous large banks in Hungary with a market share of 24 percent to approximate the amount of debt repaid through the 2011 ERP in each settlement (MNB 2018b). The second approach imputes the amount of debt prepaid in a settlement with the amount of new domestic currency borrowing (refinancing) during the window when the ERP was in operation. The third approach allocates debt prepaid per capita across settlements based on an assumed elasticity with respect to income or education. We experiment with a range of elasticities and find that the results are quantitatively similar for reasonable parameters. Finally, in online Appendix Section B, we also show that the aggregate default rate for loans in the credit registry closely matches the default rate reported separately from bank balance sheets before and during the crisis. This evidence suggests that the credit registry accurately captures the increase in credit risk during the crisis, even though some loans are missing.

\section{B. Settlement and Firm-Level Data}

The main settlement-level variables are from the Hungarian Central Statistics Office's T-Star database (KSH 2016). We proxy for settlement household durable spending using new auto registrations. KSH also provides settlement-level information on the unemployment rate, household income, tax payments, population, and net migration. Settlement-level education shares are obtained from the 2011 census (KSH 2011). We also use subregional (NUTS-4) house price indexes estimated from the National Bank of Hungary's home purchase transactions database (MNB 2017).

Firm-level data are from corporate tax filings to the Hungarian Tax Authority (NAV 2016) and include employment, payroll, export sales, and investment at the firm

status back to 2006. This backfilling potentially understates defaults before 2010, although Figure B.3 suggests it captures the aggregate default rate closely. Online Appendix Section B.1.3 provides details on the default measure. 
level for all double-bookkeeping firms in Hungary. The median firm has one establishment (including the headquarters), and, on average, a firm has establishments in 1.66 settlements. We therefore define a firm's exposure to local household FC debt by the settlement of the headquarters. ${ }^{12}$ We construct a balanced panel and exclude firms with fewer than three employees and firms in the finance, real estate, public administration, education, and health and social work sectors. This yields a panel of 66,267 firms that we follow through the crisis from 2006 to 2012. Finally, we obtain firm debt by currency and firm default by matching loan-level data from the Hungarian Firm Credit Registry (MNB 2016b).

\section{Summary Statistics}

Panels A and B of Table 1 report summary statistics for the settlement-level sample. The household FC debt share in September 2008, $s_{z 08}^{F C}$, has a mean of 66 percent and a standard deviation of 8 percentage points. The household default rate rose by 3.9 percentage points between 2008 and 2010, and the unemployment rate increased by 2.1 percentage points. Auto spending fell by 70 percent ( $1.2 \mathrm{log}$ points) on average, while house prices declined 7 percent. Panel $\mathrm{C}$ reports summary statistics for our sample of firms. Average employment growth from 2008 to 2010 was -6 percent. The average firm FC debt share is 11 percent, 18 percent of firms have FC debt, and one-fifth of firms are exporters.

\section{Theory and Empirical Framework}

\section{A. Theoretical Predictions}

We are interested in how a revaluation of household foreign currency debt affects household spending and real economic activity. In line with our empirical setting, our discussion here will focus on a permanent increase in the value of long-term household debt obligations owed to foreign creditors.

Consumption Response to a Household Debt Revaluation.- - In the benchmark case of an open economy model with complete markets, the currency composition of debt does not affect household consumption or aggregate activity. In the classic model of Backus and Smith (1993), consumption is pinned down by an international risk-sharing condition, which implies that consumption increases with a real exchange rate depreciation. Even without complete markets, households may be naturally hedged against an exchange rate depreciation through foreign currency income or wealth. Therefore, a necessary condition for a foreign currency debt revaluation to affect the real economy is for households to have unhedged exposure to FC debt.

An unhedged, permanent revaluation of long-term foreign currency debt burdens leads to an increase in present and future debt service obligations. This represents a decline in wealth for borrowers and the economy as a whole, depressing

\footnotetext{
${ }^{12}$ Information on establishment addresses is from CIO (2017). Results are similar if we only use single-establishment firms or if we take the establishment weighted average of household FC debt exposure.
} 
TABle 1 -Summary Statistics

\begin{tabular}{|c|c|c|c|c|c|}
\hline & Observations & Mean & SD & Tenth & Ninetieth \\
\hline \multicolumn{6}{|l|}{ Panel A. Foreign currency exposure } \\
\hline HH FC debt share, $s_{z 08}^{F C}$ & 2,538 & 0.66 & 0.08 & 0.56 & 0.77 \\
\hline HH debt revaluation, 2008-2010, $\Delta \tilde{d}_{z}$ & 2,538 & 22.15 & 2.20 & 19.64 & 24.97 \\
\hline HH debt to inc. revaluation, 2008-2010, $\Delta \tilde{d}_{z}^{I n c}$ & 2,538 & 16.20 & 4.23 & 11.28 & 22.06 \\
\hline \multicolumn{6}{|l|}{ Panel B. Settlement-level variables } \\
\hline Default rate change, $2008-2010$ & 2,538 & 3.85 & 2.09 & 2.32 & 5.89 \\
\hline log new auto registration change, $2008-2010$ & 2,538 & -120.93 & 44.09 & -177.07 & -83.30 \\
\hline Unemployment rate change, $2008-2010$ & 2,538 & 2.08 & 1.39 & 0.87 & 3.51 \\
\hline House price growth, $2008-2010$ & 2,538 & -6.82 & 18.45 & -23.60 & 9.85 \\
\hline Debt to disp. income, 2008 & 2,538 & 0.67 & 0.22 & 0.45 & 0.89 \\
\hline Disp. income per capita, 1,000 HUF, 2007 & 2,538 & 842.57 & 212.79 & 544.25 & $1,103.61$ \\
\hline College share & 2,538 & 0.16 & 0.08 & 0.05 & 0.29 \\
\hline Share of population age $18-59,2007$ & 2,538 & 0.61 & 0.03 & 0.59 & 0.64 \\
\hline Housing loan default rate, $2008: 9$ & 2,538 & 0.92 & 1.15 & 0.00 & 1.87 \\
\hline House price growth, 2003-2007 & 2,538 & 25.55 & 16.00 & 7.23 & 48.55 \\
\hline LTV, 2004-2008 & 2,538 & 0.62 & 0.03 & 0.58 & 0.65 \\
\hline Change in LTV, 2004-2005 to 2007-2008 & 2,538 & 0.07 & 0.05 & 0.01 & 0.11 \\
\hline Firm default rate, 2008:III & 2,538 & 5.98 & 5.81 & 0.00 & 10.00 \\
\hline \multicolumn{6}{|l|}{ Panel C. Firm-level variables } \\
\hline Employment growth, 2008-2010 & 66,267 & -6.04 & 45.31 & -66.67 & 40.00 \\
\hline Corporate FC debt share, 2007 & 66,267 & 0.11 & 0.28 & 0.00 & 0.53 \\
\hline Firm has positive FC debt & 66,267 & 0.18 & 0.38 & 0.00 & 1.00 \\
\hline Exporter & 66,267 & 0.20 & 0.40 & 0.00 & 1.00 \\
\hline Manufacturing & 66,267 & 0.18 & 0.38 & 0.00 & 1.00 \\
\hline
\end{tabular}

Notes: Panels A and B report summary statistics for settlement (municipality) level variables. Observations are weighted by 2007 population. Panel C presents summary statistics for the firm-level census sample.

consumption. The strength of the consumption decline varies with the importance of precautionary savings motives, liquidity constraints, and the remaining maturity of the debt obligation.

It is useful to first consider the consumption response in two polar cases: a permanent income (PI) consumer and a hand-to-mouth (HtM) consumer. For a PI consumer, the partial equilibrium consumption decline to the debt revaluation is the annuity value of the increase in debt, $r \Delta d$ (e.g., Hall 1978). Here, $\Delta d$ is the increase in debt and $r$ in the interest rate faced by the consumer (see online Appendix Section $\mathrm{C}$ for details). In contrast, for an HtM consumer, an extreme example of liquidity constraints, consumption declines one-for-one with the increase in per-period debt service.

When debt obligations are short term, the consumption response is substantially larger for an HtM agent. For example, if the debt is one period, the HtM consumer has to repay the entire revalued debt in that period, so the consumption decline is $(1+r) / r$ times larger than for the PI consumer. As the maturity increases, the HtM consumption response approaches the annuity value response of the PI consumer. In the limit of nonamortizing perpetual debt, the responses are identical. In our sample, the average housing loan has a remaining maturity of 18 years, which implies that the increase in debt service is about 1.5 to 2 times larger than the annuity value of the increase in debt (see online Appendix Section C). Thus, the difference between the $\mathrm{HtM}$ and PI response is an order of magnitude smaller for a revaluation of long-term debt burdens than a transitory liquidity shock. 
A variety of theories, beyond the basic HtM model, predict that the consumption response to a debt revaluation is larger than in the PI model. In the presence of a precautionary-savings motive and uninsurable income risk, consumption is concave in household net worth, so consumption is more sensitive to current resources than in the PI model (e.g., Carroll 2001). De Ferra, Mitman, and Romei (2019) develops a model of a household foreign currency debt revaluation and finds that the consumption decline is larger when debt is concentrated among poorer households. The precautionary savings model also implies that an increase in uncertainty about the future exchange rate also strengthens the consumption decline.

Theories of credit constraints also predict that consumption responds more strongly to an increase in debt service than implied by the PI model. Financial accelerator models imply that an increase in debt lowers household creditworthiness and access to new financing (e.g., Bernanke and Gertler 1989). For example, the large increase in debt can drive borrowers into negative equity, inhibiting the ability to refinance into local currency debt or lower interest rates.

Debt Revaluation and Real Activity.- How does the increase in debt affect real economic activity? This depends on macroeconomic and financial market frictions. In an open economy neoclassical model with variable labor supply, the decline in household wealth induced by the debt revaluation leads households to boost labor supply, as leisure is a normal good (e.g., Devereux and Smith 2007). With flexible prices and without other frictions, this labor supply effect translates into an increase in output. Similarly, Chari, Kehoe, and McGrattan (2005) shows that a sudden stop that forces households to repay external debt raises output through an increase in labor supply. 13

Macroeconomic frictions, such as nominal rigidities, however, can make the household debt revaluation contractionary, rather than expansionary. When prices and wages cannot adjust downward, the debt-induced decline in demand translates into lower employment and output. In online Appendix Section D, we present a standard New Keynesian small open economy model based on Galí and Monacelli (2005) that illustrates the contrasting neoclassical and Keynesian effects of a debt revaluation. Estimation of the impact of a debt revaluation, therefore, provides a test of standard flexible price versus sticky price open economy models, providing a useful "identified moment" for macroeconomic models (Nakamura and Steinsson 2018). Real rigidities, such as frictions that inhibit a reallocation of employment toward exporting firms, strengthen the negative effects of debt on output (e.g., Huo and Ríos-Rull 2016).

In the presence of nominal rigidities, household foreign currency borrowing may be excessive from a social perspective. Farhi and Werning (2016) presents a model with nominal rigidities and incomplete markets, where households can borrow using both foreign and local currency debt. In their model, borrowers do not internalize the contractionary equilibrium effects of a debt revaluation when making financing

\footnotetext{
${ }^{13}$ The labor supply expansion channel holds for most standard preferences assumed in the literature, including balanced-growth preferences. An exception is GHH (quasilinear) preferences, which eliminate the wealth effect on labor supply. Debt can also lower labor supply through a debt overhang effect (e.g., Donaldson, Piacentino, and Thakor 2016). Given that there was no consumer bankruptcy code in Hungary at the time of the crisis and therefore a small degree of limited liability, the wealth effect likely dominates the debt overhang effect in this context.
} 
decisions, implying that foreign currency debt is associated with a negative demand externality. If the exchange rate tends to depreciate in bad times, a social planner would optimally choose to tax the accumulation of foreign currency debt.

Financing frictions can also amplify the equilibrium decline in consumption and output. The rise in debt may increase defaults and foreclosures, leading to fire sales that depress local house prices. A decline in house prices lowers household net worth and can tighten collateral constraints, further lowering consumption (Kiyotaki and Moore 1997). A worse recession itself also depresses house prices, creating a two-way feedback between the demand and fire-sale channels. The decline in demand may also put downward pressure on domestic prices and reinforce the initial exchange rate depreciation, further increasing the value of foreign currency debt. Models of "international debt-deflation" stress the role of collateral constraints in amplifying the balance sheet effects of foreign currency debt following a depreciation (e.g., Mendoza 2010, Korinek 2011).

What about an offsetting increase in spending by savers? In a closed economy, a debt revaluation would represent a transfer to savers, who can offset the decline in spending by borrowers. If savers have a lower marginal propensity to consume (MPC) than borrowers, the shock would still depress aggregate consumption, as in the two-agent model of Eggertsson and Krugman (2012). In the small open economy context, the MPC of foreign savers on the output of the small open economy is likely close to zero. In this regard, the international debt revaluation examined in this paper can be seen as analogous to the closed economy case where savers have an MPC of zero.

\section{B. Empirical Specification}

Our empirical specification isolates the debt revaluation channel by comparing the evolution of outcomes in regions with high exposure to foreign currency debt, relative to regions with low exposure, around depreciation of the Hungarian forint that started in October 2008. The basic empirical specification is

$$
y_{z t}=\alpha_{z}+\gamma_{t}+\beta(\text { HH FC Debt Exposure })_{z 08} \times \text { Post }_{t}+\epsilon_{z t},
$$

where $y_{z t}$ is an outcome such as spending in settlement $z,(\text { HH FC Debt Exposure })_{z 08}$ is a measure of household exposure to FC debt prior to the depreciation, $\alpha_{z}$ and $\gamma_{t}$ are settlement and time fixed effects, respectively, and Post $t_{t}$ is a variable that equals 0 up to 2008 and 1 from 2009 onward.

We also estimate the impact of the household debt revaluation over time to test for pretrends and the full dynamic propagation of the shock using

$$
y_{z t}=\alpha_{z}+\gamma_{t}+\sum_{k \neq 2008}\left[\beta_{k}(\text { HH FC Debt Exposure })_{z 08} \times \mathbf{1}_{k=t}\right]+\epsilon_{z t},
$$

where $\mathbf{1}_{k=t}$ is an indicator that equals 1 in year $t$ and 0 otherwise. We estimate (1) and (2) using a balanced panel of 2,538 settlements, but we cluster standard errors on 175 subregions based on a test of the appropriate level of clustering developed by Ibragimov and Müller (2016). Our preferred specification weights by settlement 
population in 2007, but we report robustness checks with alternative weighting schemes.

Our baseline measure of local exposure to foreign currency debt is the share of household debt in foreign currency in September 2008, $s_{z 08}^{F C}$. In September 2008, 97 percent of FC debt was denominated in Swiss franc. A settlement's share of household debt in FC thus captures most of the variation in exposure to the depreciation. Online Appendix Figure A.3 presents a map of the spatial variation in the household FC debt share, $s_{z 08}^{F C}$. The share of household debt in foreign currency is not strongly clustered in specific regions. The FC debt share ranges from 48 percent on average in the lowest decile to 90 percent in the highest decile, and there is variation in the currency composition of debt within and across major regions.

To obtain estimates that are more easily interpretable, we also directly estimate the effect of the household debt revaluation shock from 2008:9 to $t$, defined as

$$
\Delta_{08-t} \tilde{d}_{z}=\frac{\sum_{j \in C}\left(\mathcal{E}_{t}^{j} D_{z 08}^{j}-\mathcal{E}_{08}^{j} D_{z 08}^{j}\right)}{\sum_{j \in C} \mathcal{E}_{08}^{j} D_{z 08}^{j}}
$$

where $C$ is the set of currencies, $\mathcal{E}_{t}^{j}$ is the forint price of currency $j$ at time $t$, and $D_{z 08}^{j}$ is debt in currency $j$ in September 2008. The debt revaluation shock captures the percentage increase in debt induced by the depreciation.

The FC debt share and the debt revaluation shock exploit variation in the currency composition of household debt, but not the overall level of leverage. This allows us to hold fixed the overall expansion in debt, which may be correlated with other cyclical factors. While this is appealing from an identification perspective, from a theoretical perspective the overall increase in debt burdens relative to household resources is what matters. We therefore also present results using the household debt revaluation relative to income, which is defined as

$$
\Delta_{08-t} \tilde{d}_{z}^{\text {Inc }}=\frac{\sum_{j \in C}\left(\mathcal{E}_{t}^{j} D_{z 08}^{j}-\mathcal{E}_{08}^{j} D_{z 08}^{j}\right)}{(\text { Household disp. income })_{z 08}} .
$$

The correlation between this measure and the FC debt share is 0.26 . Finally, we present robustness using alternative measures of exposure, including the number of FC loans per adult.

\section{Identification and Variation in Household FC Debt}

Equation (1) provides a consistent estimate of $\beta$ under the identifying assumption of parallel trends. More precisely, identification assumes that the change in an outcome $y_{z t}$ in low $s_{z 08}^{F C}$ settlements is a valid counterfactual for high $s_{z 08}^{F C}$ settlements, had those regions not been exposed to the depreciation through household FC debt. The threat to identification is a time-varying, region-specific shock that affects $y_{z t}$ and is correlated with exposure to foreign currency debt.

A potential concern with our empirical strategy is that FC and LC borrowers may have different exposure to business cycle risk. A priori, the sign of such potential 
Table 2-Local and Foreign Currency Borrowers in Household Survey Data

\begin{tabular}{lccccc}
\hline \hline & $\begin{array}{c}\text { LC } \\
\text { mean }\end{array}$ & $\begin{array}{c}\text { FC } \\
\text { mean }\end{array}$ & $\begin{array}{c}\text { Nonborrower } \\
\text { mean }\end{array}$ & $\begin{array}{c}\text { FC - LC } \\
\text { difference }\end{array}$ & $\begin{array}{c}\text { FC - LC } \\
\text { standard error }\end{array}$ \\
\hline Low education & 0.18 & 0.12 & 0.27 & -0.06 & 0.01 \\
Medium education & 0.64 & 0.67 & 0.57 & 0.04 & 0.02 \\
High education & 0.18 & 0.20 & 0.16 & 0.02 & 0.02 \\
Low income & 0.30 & 0.24 & 0.35 & -0.06 & 0.02 \\
Medium income & 0.30 & 0.26 & 0.25 & -0.04 & 0.02 \\
High income & 0.27 & 0.32 & 0.21 & 0.05 & 0.02 \\
Age in 2008 & 41.50 & 40.56 & 48.26 & -0.93 & 0.49 \\
Household size & 2.91 & 3.05 & 2.44 & 0.14 & 0.05 \\
Employed & 0.62 & 0.69 & 0.43 & 0.07 & 0.02 \\
City population $<5,000$ & 0.33 & 0.32 & 0.29 & -0.01 & 0.02 \\
City population 5,000 to 100,000 & 0.42 & 0.46 & 0.40 & 0.04 & 0.02 \\
City population $>100,000$ & 0.25 & 0.22 & 0.31 & -0.02 & 0.02 \\
Observations & 1,171 & 1,355 & 6,587 & 2,526 & 2,526 \\
\hline
\end{tabular}

Notes: This table presents average individual-level characteristics of LC borrowers, FC borrowers, and nonborrowers from the Austrian Central Bank's Euro Survey Project. We pool the biannual samples from 2008 to 2011. Education and income are reported in three categorical groups (low, medium, and high). Foreign (local) currency borrowers are borrowers who report have loans that are solely or predominantly in foreign (local) currency.

selection into FC loans is ambiguous, both at the individual and regional level. Households with higher or less risky income may be more likely to borrow in foreign currency. ${ }^{14}$ Foreign banks, the main providers of FC credit, may also "cherry-pick" borrowers with low default risk. On the other hand, less financially sophisticated households who are more exposed to recession risk may be more likely to borrow in FC because they do not adequately assess exchange rate risk.

Table 2 presents the average characteristics of LC borrowers, FC borrowers, and nonborrowers from a representative survey of households in Hungary collected by the Austrian Central Bank's Euro Survey Project (OeNB 2018). We use households from the 2008 to 2011 waves of the survey. ${ }^{15}$ Compared to LC borrowers, FC borrowers have similar or slightly higher education, income, and employment rates. FC borrowers also tend to be younger and live in smaller towns. Notably, the difference between FC and LC borrowers is substantially smaller than between borrowers and nonborrowers, with borrowers having higher average education and income. 16 A borrower's loan currency denomination is largely determined by whether the loan was taken out during the subsidized LC period or the FC lending period. This explains why FC and LC borrowers are likely to be reasonably similar along most dimensions, but also why FC borrowers are younger on average.

\footnotetext{
${ }^{14}$ For example, Beer, Ongena, and Peter (2010) finds that Swiss franc borrowers in Austria are typically high-income and financially sophisticated households.

${ }^{15}$ The Euro Survey Project is a biannual survey that collects information on the role of the euro and other foreign currencies in Central and Eastern European countries. Results are similar, but less precise, using only the 2008 wave. Because lending effectively stopped after the depreciation, most borrowers with an FC loan after 2008 would have borrowed prior to the depreciation.

${ }^{16}$ Online Appendix Table A.1 shows that these patterns are similar using another individual-level survey dataset, the Tarki Household Monitor (TARKI 2019), which also contains information on individuals' loan currency denomination. Other studies using the Euro Survey and other households surveys also find that FC and LC borrowers in Hungary are broadly similar along observable dimensions (Fidrmuc, Hake, and Stix 2013; Pellényi and Bilek 2009).
} 
Table 3-Correlates of Household FC Debt Exposure across Settlements

\begin{tabular}{lcccc}
\hline \hline Right-hand-side variable & Coefficient & Standard error & $R^{2}$ & Observations \\
\hline Debt to disposable income, 2008:9 & -0.034 & 0.017 & 0.008 & 2,538 \\
log disposable income per capita, 2007 & -0.064 & 0.015 & 0.048 & 2,538 \\
log population, 2007 & -0.006 & 0.002 & 0.031 & 2,538 \\
Share of population age 18-59, 2007 & -0.228 & 0.136 & 0.005 & 2,538 \\
Vocational education share & 0.332 & 0.097 & 0.044 & 2,538 \\
High school share & -0.284 & 0.061 & 0.051 & 2,538 \\
College share & -0.274 & 0.089 & 0.079 & 2,538 \\
Unemployment rate, 2007 & 0.369 & 0.096 & 0.044 & 2,538 \\
Household default rate, 2008:9 & 0.705 & 0.222 & 0.010 & 2,538 \\
Firm default rate, 2008:III & 0.101 & 0.033 & 0.005 & 2,538 \\
House price growth, 2003-2007 & 0.133 & 0.028 & 0.067 & 2,538 \\
House price growth, 2005-2007 & 0.050 & 0.040 & 0.006 & 2,538 \\
LTV, 2004-2008 & -0.090 & 0.130 & 0.001 & 2,538 \\
Change in LTV, 2004-2005 to 2007-2008 & -0.158 & 0.066 & 0.009 & 2,538 \\
Export sales share, 2007 & -0.026 & 0.028 & 0.007 & 2,538 \\
Export sales per capita, 2007 & -0.168 & 0.630 & 0.000 & 2,538 \\
log sales-employment ratio, 2007 & -0.011 & 0.008 & 0.008 & 2,538 \\
Corporate FC indebtedness, 2008, $s_{\text {z08 }}^{F C \text { Firm }}$ & -0.012 & 0.022 & 0.001 & 2,538 \\
Manufacturing employment share, 2007 & 0.008 & 0.019 & 0.001 & 2,538 \\
Construction employment share, 2007 & 0.011 & 0.038 & 0.000 & 2,538 \\
Agriculture employment share, 2007 & 0.042 & 0.023 & 0.005 & 2,538 \\
\hline
\end{tabular}

Notes: The table presents regressions of the September 2008 household foreign currency debt share on various settlement level characteristics: $s_{z 08}^{F C}=\alpha+\beta x_{z}+u_{z}$. Observations are weighted by 2007 population. Standard errors are clustered at the subregion level (175 units).

While FC and LC borrowers are similar at the individual level, our analysis primarily exploits regional variation to examine the impact on local aggregate economic activity. Table 3 presents regressions of $s_{z 08}^{F C}$ on various settlement-level characteristics to provide a sense of the correlates of local HH FC debt exposure. The FC debt share is uncorrelated or weakly correlated with overall household debt to income, the average LTV ratio, export exposure of local firms, manufacturing and construction employment shares, and corporate FC indebtedness. The household FC debt share is also uncorrelated with house price growth from 2005 to 2007, but positively correlated with house price growth from 2003 to 2007.

At the same time, Table 3 reveals that high $s_{z 08}^{F C}$ areas have significantly lower disposable income per capita, education levels, and population and higher precrisis unemployment. Areas with higher household FC debt exposure also have significantly higher precrisis default rates on household loans, though these relations are generally moderate in magnitude and goodness-of-fit. That is, while FC and LC borrowers are approximately comparable at the individual level according to survey data, FC borrowers tend to live in smaller cities with lower overall income and education and higher credit risk on some dimensions.

One explanation for the negative relation between $s_{z 08}^{F C}$ and local population, income, and education comes from the credit supply side. Following the transition from communism, average retail banking depth and competition were low, but varied substantially across regions. ${ }^{17}$ Areas with a higher density of domestic banks experienced stronger growth in subsidized domestic currency household

\footnotetext{
${ }^{17}$ Gál (2005) provides a detailed analysis of the geographic differences in the density of retail banking after the transition from communism, showing that there were significant differences in the number of retail banks per
} 
credit. Following the cutback of domestic currency subsidies in 2004, foreign banks filled into areas with lower branch density, providing FC credit to previously underserved areas. Online Appendix Table A.2 shows that areas with a higher banking density in 1995 have a higher domestic currency debt-to-income in 2008, lower FC debt-to-income, and therefore a lower share of debt in FC.

In the empirical analysis below, we report estimates that control for precrisis settlement-level observables in Table 3, interacted with the Post $t_{t}$ indicator, to capture any time-varying shocks that interact with these observables. In particular, we present tests that control for September 2008 debt to disposable income, log 2007 population, log 2007 disposable income per capita, education (vocational, high school, and college) shares, the population shares age 18-59 and above 60, and the intensity of a public jobs program that was expanded in 2011 (Baseline controls). 18

To capture potential differences in ex ante credit quality, we control for the precrisis household and firm default rates (measured in 2008:III), house price growth from 2003 to 2007, average LTV from 2004 to 2008, and the change in LTV between 2004-2005 and 2007-2008 (Credit quality controls). We also control for time-varying regional shocks by including fixed effects for seven major regions (Region fixed effects). In addition, we present tests that control for one-digit industry employment shares, export revenues as a share of total firm revenues, and export revenues per capita (Industry employment shares and Export exposure controls). In firm-level employment regressions, we include firm-level measures of productivity, size, firm leverage and firm FC indebtedness, ownership structure, and two-digit industry fixed effects (Firm controls).

\section{Main Results}

\section{A. Household Default}

Panel A of Table 4 analyzes the effect of the household foreign currency debt revaluation on the settlement-level household default rate. Column 1 presents the estimate of equation (1), controlling only for settlement and time fixed effects. The estimation sample is a quarterly settlement level panel from 2006:I to 2012:IV. The estimate implies that taking the FC debt share from 0 to 1 is associated 9.30 percentage point higher default rate after the depreciation. In columns 2 and 3 we progressively include the controls sets defined in the previous section. The estimate falls to 5.73 , but remains highly significant. In terms of which controls matter most, we find that once we control for education shares, the estimates are stable when adding additional controls. 19

capita across regions. He argues these differences are driven by a high degree of centralization in a few major cities dating back to communism.

${ }^{18}$ The public jobs program was targeted toward regions with the largest rise in unemployment, and the program attenuates the estimated effect on unemployment (but not employment) starting in 2012, as seen by comparing Figure 5 and online Appendix Figure A.4.

${ }^{19}$ Online Appendix Table A.4 explores the impact of adding various control sets more systematically. Table A.4 shows that once education shares are included as controls, the estimates are stable when adding a broad range of additional controls, including controls for local demographics, household income, credit quality, export exposure, and industry shares. 
Table 4-Household Debt Revaluation, Local Default Rates, and Durable Spending

\begin{tabular}{|c|c|c|c|c|c|}
\hline & (1) & $(2)$ & (3) & (4) & $(5)$ \\
\hline \multicolumn{6}{|c|}{ Panel A. Default rate (quarterly panel estimation) } \\
\hline HH FC debt share, $s_{z 08}^{F C} \times$ post & $\begin{array}{c}9.30 \\
(1.02)\end{array}$ & $\begin{array}{c}5.65 \\
(0.69)\end{array}$ & $\begin{array}{c}5.73 \\
(0.68)\end{array}$ & & \\
\hline HH debt revaluation, $\Delta \tilde{d}_{z} \times$ post & & & & $\begin{array}{c}0.20 \\
(0.025)\end{array}$ & \\
\hline HH debt to inc. revaluation, $\Delta \tilde{d}_{z}^{I n c} \times$ post & & & & & $\begin{array}{c}0.15 \\
(0.019)\end{array}$ \\
\hline$R^{2}$ & 0.84 & 0.87 & 0.87 & 0.87 & 0.87 \\
\hline Number of settlements & 2,538 & 2,538 & 2,538 & 2,538 & 2,538 \\
\hline Observations & 71,064 & 71,064 & 71,064 & 71,064 & 71,064 \\
\hline \multicolumn{6}{|c|}{ Panel B. New auto registrations (annual panel estimation) } \\
\hline HH FC debt share, $s_{z 08}^{F C} \times$ post & $\begin{array}{l}-109.1 \\
(16.6)\end{array}$ & $\begin{array}{l}-53.0 \\
(9.10)\end{array}$ & $\begin{array}{l}-53.1 \\
(8.92)\end{array}$ & & \\
\hline HH debt revaluation, $\Delta \tilde{d}_{z} \times$ post & & & & $\begin{array}{l}-2.01 \\
(0.33)\end{array}$ & \\
\hline HH debt to inc. revaluation, $\Delta \tilde{d}_{z}^{I n c} \times$ post & & & & & $\begin{array}{l}-1.26 \\
(0.35)\end{array}$ \\
\hline$R^{2}$ & 0.82 & 0.84 & 0.85 & 0.85 & 0.85 \\
\hline Number of settlements & 2,538 & 2,538 & 2,538 & 2,538 & 2,538 \\
\hline Observations & 17,766 & 17,766 & 17,766 & 17,766 & 17,766 \\
\hline Settlement and time fixed effects & Yes & Yes & Yes & Yes & Yes \\
\hline Baseline controls & & Yes & Yes & Yes & Yes \\
\hline Region fixed effects ( 7 units) & & Yes & Yes & Yes & Yes \\
\hline Credit quality controls & & Yes & Yes & Yes & Yes \\
\hline Export exposure controls & & & Yes & Yes & Yes \\
\hline Industry employment shares & & & Yes & Yes & Yes \\
\hline
\end{tabular}

Notes: This table presents estimates of equation (1) for the household default rate (panel A) and the log number of new auto registration (panel B). The default rate is measured as the fraction of loans in arrears in a settlement (city or municipality). Columns 1-3 use the household FC debt share as the measure of household FC debt exposure, while columns 4 and 5 report results using the household debt revaluation measures defined in equations (3) and (4). All controls are interacted with Post, an indicator that equals 1 from 2009 onward. Baseline controls are 2007 household disposable income, 2008:III household debt-to-income, 2007 log population, education shares, 2007 18-59 and 60+ population shares, and public employment program intensity. Region fixed effects refer to 7 major regions (NUTS-2). Credit quality controls are the 2008:III household default rate, 2003 to 2007 house price growth, a proxy for average LTV at origination, the change in average LTV between 2004-2005 and 2007-2008, and the firm default rate in 2008:III. Export exposure controls are the export share of firm revenues and total firm export revenues per capita. Industry employment shares refer to one-digit NACE industries. Observations are weighted by 2007 population. Standard errors are clustered at the subregion level (175 units).

The estimated impact on the household default rate is large in magnitude. Applying the estimate to the average household FC debt exposure implies that household FC debt explains 71 percent $(5.73 \times 0.66 / 5.29)$ of the average rise in the default rate from the precrisis to the crisis period. This calculation abstracts from general equilibrium effects across local areas, which we discuss in Section IVD. Housing loans in Hungary are full recourse loans, and debt cannot be discharged in bankruptcy. Thus, a household's decision to default mainly reflects limited ability, as opposed to willingness, to repay. The large rise in defaults caused by exposure to foreign currency debt, therefore, represents a severe increase in household financial distress.

Figure 3 presents the effect of FC debt exposure on the default rate over time from estimating (2). The evolution of the default rate in high and low FC debt regions is similar prior to the depreciation. Higher FC debt regions experience a gradual rise in default rates starting in 2009:I. The gradual rise is likely due to a combination 


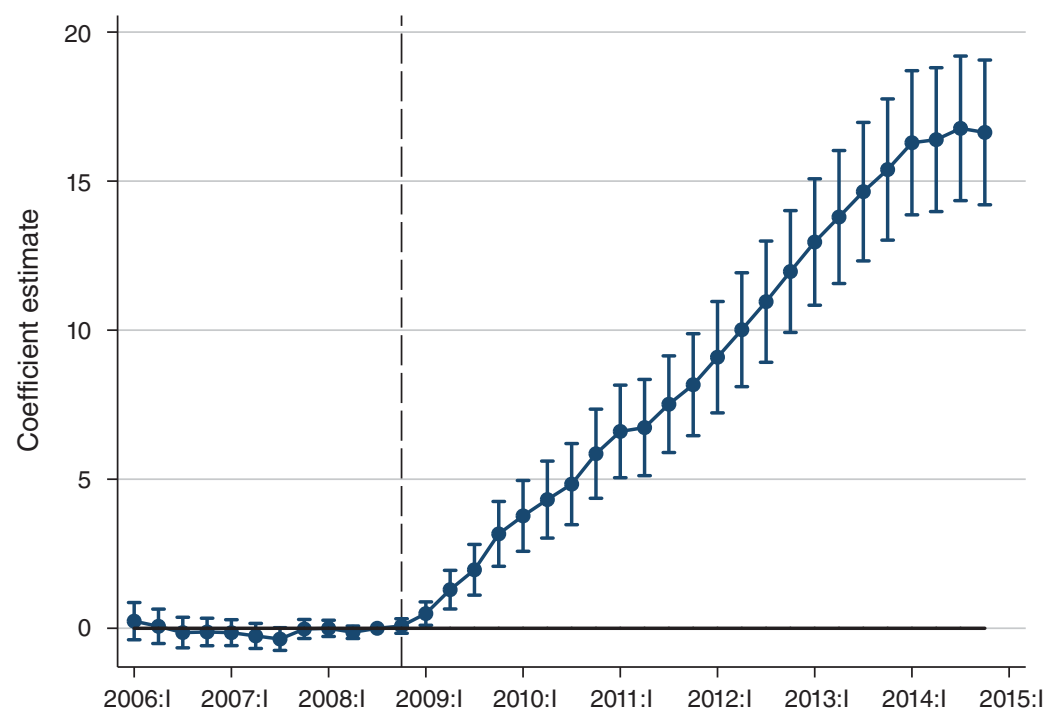

Figure 3. Household Foreign Currency Debt Exposure and Default Rates

Notes: This figure presents results from estimating (2) for the settlement household default rate, defined as the fraction of housing loans in default. Control variables in $X_{z}$ correspond to all the controls in column 3 of Table 4 interacted with the full set of times dummies. Online Appendix Figure A.4 presents the estimates without controls. The omitted period is 2008:III, the last quarter before the depreciation. Observations are weighted by 2007 population. Error bars represent 95 percent confidence intervals from standard errors clustered at the subregion level.

of the additional depreciation and the full recourse environment, which provides an incentive to avoid default.

Column 4 in Table 4 presents the estimated effect in terms of the household debt revaluation shock, $\Delta \tilde{d}_{z}$, defined in (3). To fix the size of the shock affecting a given settlement, the debt revaluation is measured based on the average depreciation against the Swiss franc from the outbreak of the crisis until 2012 (36 percent). This specification can be thought of as the "second stage" regression of the effect of debt revaluation on default, where the second stage variable is computed as the exact debt revaluation shock implied by FC debt exposure. Column 4 implies that a 10 percent increase in household debt raises the settlement default rate by 2 percentage points.

Column 5 in Table 4 presents the same regression with the household debt revaluation to income, defined in (4), as the right-hand-side variable. According to this specification, a 10 percentage point increase in debt-to-income raises the local default rate by 1.5 percentage points. ${ }^{20}$ In contrast to the FC debt share $\left(s_{z 08}^{F C}\right)$, the debt revaluation relative to income is positively correlated with income and education (see online Appendix Table A.3). The fact that we find similar results with this measure suggests that the baseline results are not driven by an unobservable shock that differentially affects poorer regions.

\footnotetext{
${ }^{20}$ Online Appendix Table A.5 presents a simpler cross-sectional specification of the change in various outcomes from 2008 to 2010 on the household debt revaluation measures, $\Delta \tilde{d}_{z, 08-10}$ and $\Delta \tilde{d}_{z, 08-10}^{I n c}$, defined over the same period. The estimates from this simpler specification are similar to the estimates in Table 4.
} 


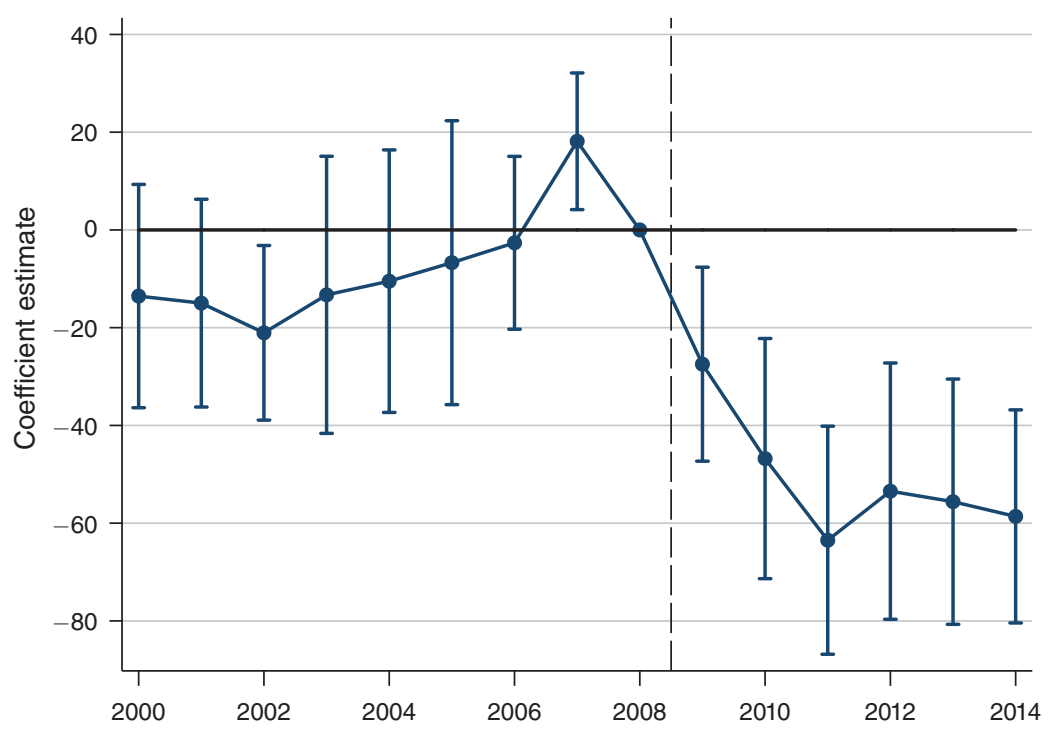

Figure 4. Foreign Currency Debt Exposure and Household Spending

Notes: This figure presents results from estimating (2) for durable spending (log new auto registrations). Coefficients are multiplied by 100 . Observations are weighted by 2007 population. Error bars represent 95 percent confidence intervals from standard errors clustered at the subregion level.

\section{B. Durable Spending}

In panel B of Table 4, we ask whether the household debt revaluation translates into a decline in local spending on durables. Columns 1-3 report estimates of equation (1) with the log of the number of new auto registrations as the dependent variable. ${ }^{21}$ The estimates imply that settlements with full exposure to FC debt experience a 41 percent $(0.53 \log$ point $)$ decline in auto purchases relative to regions with no foreign currency debt. In terms of magnitudes, the estimate implies that household FC debt accounts for 34 percent $(-53.1 \times 0.66 / 101.5)$ of the average decline in auto spending in the crisis, abstracting from aggregate equilibrium effects. The estimated effect is highly significant and robust to including a host of controls. However, it is important to note that the point estimate declines by one-half with the inclusion of controls, especially the education controls.

Columns 4 and 5 in panel B report the estimated effect on new auto registrations using the household debt revaluation variables as the measures of the shock. Both measures imply that the debt revaluation translates into a highly significant decline in durable spending. The estimate in column 5 implies that a 1 percentage point increase in debt to income lowers durable spending by 1.26 percent.

Figure 4 illustrates how FC debt exposure affects new auto registrations over time by plotting estimates of $\left\{\beta_{k}\right\}$ from equation (2). In the years leading up to the depreciation, auto spending evolves similarly in high relative to low $s_{z 08}^{F C}$ settlements. There is some evidence of relatively rapid growth in high exposure areas in 2003

\footnotetext{
${ }^{21}$ To allow for small settlements with zero auto registrations, we add one before taking $\operatorname{logs}$, i.e., $\ln \left(1+C_{z t}\right)$. The estimates are quantitatively similar when dropping small settlements with zero auto registrations.
} 
Table 5-Impact of Household Debt Revaluation on Local Unemployment

\begin{tabular}{|c|c|c|c|c|c|}
\hline & \multicolumn{5}{|c|}{2006 to 2012 annual panel estimation } \\
\hline & (1) & $(2)$ & (3) & $(4)$ & $(5)$ \\
\hline HH FC debt share, $s_{z 08}^{F C} \times$ post & $\begin{array}{c}2.42 \\
(0.75)\end{array}$ & $\begin{array}{c}1.62 \\
(0.51)\end{array}$ & $\begin{array}{c}1.65 \\
(0.52)\end{array}$ & & \\
\hline HH debt revaluation, $\Delta \tilde{d}_{z} \times$ post & & & & $\begin{array}{c}0.060 \\
(0.019)\end{array}$ & \\
\hline HH debt to inc. revaluation, $\Delta \tilde{d}_{z}^{I n c} \times$ post & & & & & $\begin{array}{c}0.036 \\
(0.013)\end{array}$ \\
\hline Settlement and year fixed effects & Yes & Yes & Yes & Yes & Yes \\
\hline Baseline controls & & Yes & Yes & Yes & Yes \\
\hline Region fixed effects ( 7 units) & & Yes & Yes & Yes & Yes \\
\hline Credit quality controls & & Yes & Yes & Yes & Yes \\
\hline Export exposure controls & & & Yes & Yes & Yes \\
\hline Industry employment shares & & & Yes & Yes & Yes \\
\hline$R^{2}$ & 0.61 & 0.65 & 0.65 & 0.65 & 0.65 \\
\hline Number of settlements & 2,538 & 2,538 & 2,538 & 2,538 & 2,538 \\
\hline Observations & 17,766 & 17,766 & 17,766 & 17,766 & 17,766 \\
\hline
\end{tabular}

Notes: This table presents estimates of specification (1) with the settlement unemployment rate as the dependent variable. Columns 1-3 use the household FC debt share in September 2008 as the measure of FC debt exposure. Columns 4 and 5 replace the household FC debt share with the household debt revaluation shock measures, defined in equations (3) and (4). All controls are interacted with post and are defined in Table 4. Observations are weighted by 2007 population. Standard errors are clustered at the subregion level (175 units).

and 2007, though this increase is substantially smaller than the subsequent decline. In 2009, following the depreciation, auto spending falls sharply in regions with a higher FC share and continues to fall in 2010, remaining significantly below the precrisis level even by 2014. The persistent effect on durable expenditure is consistent with the fact that debt revaluation permanently increases household debt service requirements.

\section{Local Unemployment}

The rise in the real burden of foreign currency household debt leads to a rise in default rates and a sharp decline in durable spending. How does the local economy absorb this shock? Table 5 explores the effect of the household debt revaluation on the settlement unemployment rate. Column 1 reveals that settlements with higher exposure to household FC debt see a larger rise in unemployment after the depreciation. Columns 2 and 3 show that the effect is robust to the inclusion of a variety of controls. The coefficient in column 3 implies that a region with full exposure to FC debt experiences a 1.65 percentage point increase in unemployment, relative to a region with only domestic currency debt. Based on the estimate in column 3, the debt revaluation channel accounts for 49 percent $(1.65 \times 0.66 / 2.22)$ of the increase in the unemployment rate during the crisis in a partial equilibrium sense. Hence, household FC debt can explain a substantial fraction of the labor market deterioration in the crisis.

Columns 4 and 5 report the estimates in terms of the debt revaluation measures, defined in (3) and (4). Both estimates are highly statistically significant. The 


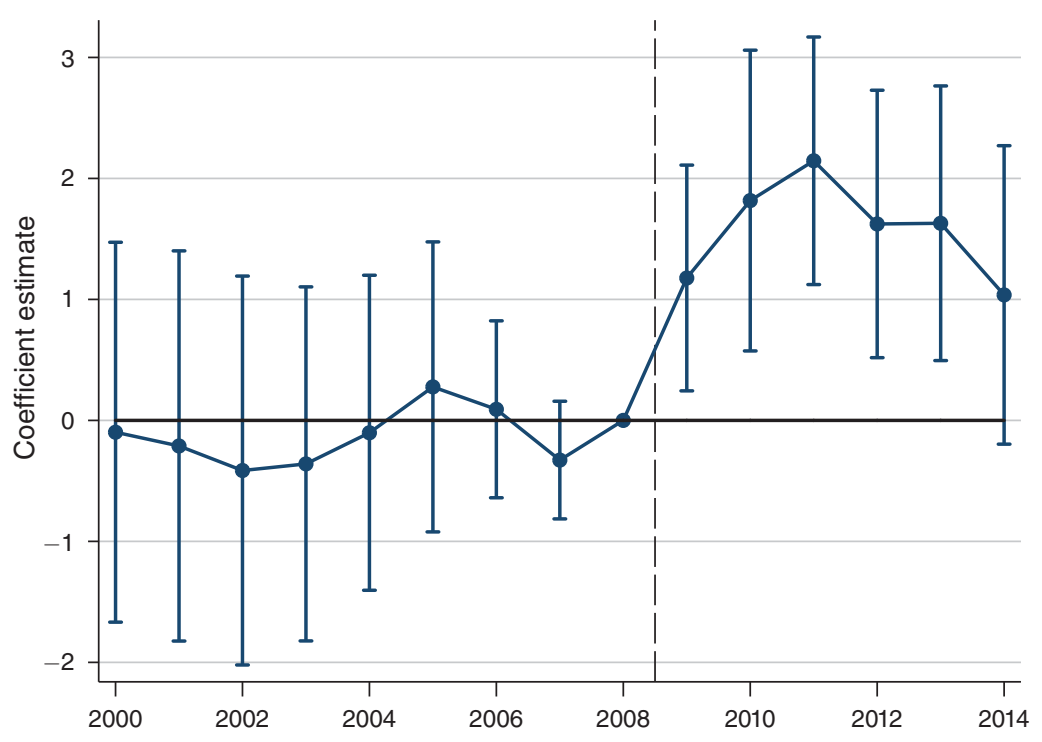

Figure 5. Foreign Currency Debt Exposure and Unemployment

Notes: This figure presents results from estimating (2) for the settlement unemployment rate. Observations are weighted by 2007 population. Error bars represent 95 percent confidence intervals from standard errors clustered at the subregion level.

estimate in column 5 on the debt revaluation to income implies that a 10 percentage point increase in household debt-to-income raises the local unemployment rate by 0.36 percentage points.

Figure 5 presents the full dynamic impact of FC debt exposure on unemployment from estimating equation (2). During the precrisis period from 2000 to 2008 , there is a limited relation between $s_{z 08}^{F C}$ and the change in unemployment, consistent with parallel trends. After the depreciation in late 2008, the coefficient rises gradually to 2.3 percentage points in 2011 , and unemployment remains persistently higher in more exposed regions for several years. By 2014, six years after the initial shock, unemployment in exposed regions had still not fully recovered to its relative precrisis level.

\section{Interpretation: The Debt Revaluation Multiplier}

The evidence that the household debt revaluation leads to a rise in default rates and a collapse in spending is consistent with models of incomplete markets where agents have unhedged exposure to FC debt. The rise in local unemployment caused by the household debt revaluation is qualitatively consistent with macroeconomic frictions such as nominal rigidities that translate the decline in demand into higher unemployment, as discussed in Section IIIA. Moreover, the results imply that the higher burden of debt leads to a significantly weaker local economy, which, in turn, exacerbates the burden of debt repayment.

What is the quantitative impact of the household debt revaluation? To answer this question, we compute the multiplier on the increase in debt service induced by 
the household debt revaluation. We follow recent studies that estimate government spending multipliers by computing "integral multipliers," which capture the cumulative response to a cumulative shock (Ramey 2016). In our context, the integral multiplier relates cumulative implied jobs lost to the cumulative increase in household debt service:

$$
M_{h}^{J o b}=\frac{\sum_{j=2009}^{h} \text { JobsLost }_{j}}{\sum_{j=2008: 9}^{h} \text { DebtServiceShock }_{j}}
$$

We calculate the numerator using the estimated effect on unemployment in Figure 5, combined with the distribution of household FC debt exposure. This calculation implies that the debt revaluation led to an increase of 9.4 unemployment-rate-years from 2009 to 2014, or 1.6 percentage points per year. Applying this to the total labor force in 2008 implies that the shock destroyed 259 thousand job-years from the start of the crisis through 2014, or 43,000 jobs per year. To compute the denominator in (5), we use the cumulative increase in households' monthly debt service from the initial depreciation through the end of year $h$, which equals US\$-PPP 10.5bn for $h=2014$ (5.2 percent of GDP).

Relating the number of job-years lost from 2009 to 2014 with the increase in debt service implies that a $\$ 40,500$ (2008 PPP, or HUF 5.3 million) increase in debt service destroys one job-year. This provides the analogue of the "cost-per-job" estimated in studies on the impact of government spending on employment. We can obtain a back-of-the-envelope estimate of the output multiplier by relating this number to nominal GDP per worker in 2008 (\$49,800 PPP). This calculation implies that for each $\$ 1$ increase in debt service, output declines by $\$ 1.23$. This estimate is based on the full cumulative impact from 2009 to 2014 . We can also examine the implied output multiplier over time by varying $h$ in our calculation. Figure 6 shows the results. At the peak effect in 2010, a \$29,000 (2008 PPP, or HUF 3.9 million) shock to debt service destroys one job-year, corresponding to a peak output multiplier of 1.67 .

Is the magnitude of this estimated multiplier reasonable? Recall that the MPC out of the increase in debt service for a hand-to-mouth agent is 1 , and for a PI agent it is approximately $1 / 2$ to $2 / 3$, given the persistence of the increase in future debt service. Supposing that the increase in debt service translates one for one into a decline in consumption, we can compare this to the multiplier on deficit or outside financed government spending estimated using cross-regional variation. Surveying the recent literature, Chodorow-Reich (2019) reports that many studies find multipliers in the range of 1.5 to 2 . Thus, our peak estimated debt revaluation multiplier of 1.67 appears to be within the range of cross-sectional fiscal multipliers.

This cross-sectional multiplier abstracts from a variety of aggregate general equilibrium effects. This raises the question of how this cross-sectional multiplier relates to the aggregate multiplier. There are several contrasting general equilibrium considerations. Leakage of local demand through purchases of goods produced in other areas within the economy implies that the aggregate multiplier is larger than the cross-sectional multiplier. Similarly, a decline in relative prices in affected areas may lead to expenditure switching toward tradable goods produced by these areas, which also implies a larger aggregate multiplier. In contrast, interregional factor 


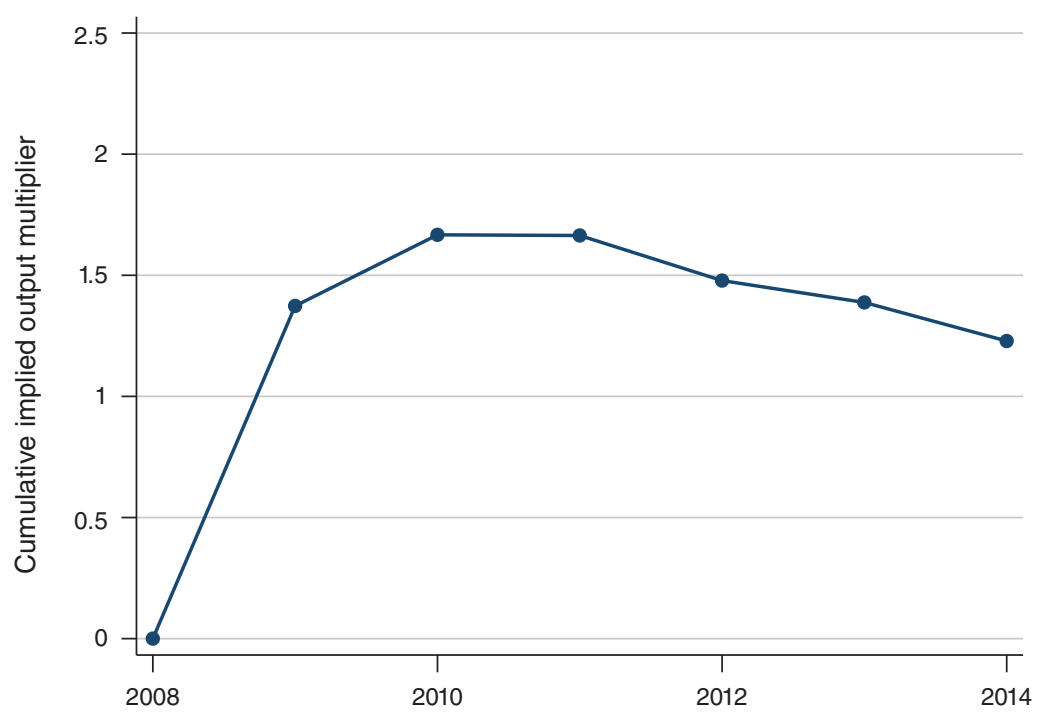

Figure 6. IMPLied OutPut Multiplier

Notes: This figure presents the cumulative output multiplier implied by the estimates from Figure 5. See text for details on computation.

mobility, such as out-migration from more affected areas to other domestic areas, would imply a smaller aggregate multiplier. In the next section, we find no expansion in employment among local exporters, limited evidence of a decline in local wages, and no differential out-migration from exposed areas. This suggests that adjustment through expenditure switching and factor mobility are limited in the short term.

A potentially important general equilibrium effect that we cannot estimate is any additional depreciation caused by the debt shock. An additional depreciation has both positive effects, by improving competitiveness, and negative effects, by reinforcing the debt revaluation. Overall, these considerations suggest that our cross-sectional multiplier can be seen as an approximation to the national aggregate multiplier of a revaluation in long-term household debt, holding fixed the exchange rate and monetary policy. ${ }^{22}$

\section{E. Robustness}

Omitted Variables and Alternative Hypotheses.-Online Appendix Table A.6 constructs parameter bounds that assess robustness to omitted variable bias based on Oster (2019). The bounds assume that selection on unobservables is proportional to selection on observables. Using the parametrization recommended by Oster (2019), the bounds for our main outcomes exclude zero. The identified sets for the default, durable spending, and unemployment estimates are $(5.7,4.3),(-53.1,-33.1)$, and $(1.7,1.4)$, respectively.

\footnotetext{
${ }^{22}$ See Chodorow-Reich (2019) for an extensive discussion of the relationship between cross-sectional and aggregate multipliers.
} 
A concrete threat to identification is that areas with higher exposure to foreign currency debt are inherently more cyclical. So far we have controlled for several factors that may capture local cyclicality, including education and industrial composition. Column 1 of online Appendix Table A.7 goes a step further and shows that the estimates are robust to controlling for a settlement's historical cyclicality. As additional evidence, online Appendix Figure A.5 uses the 1998 Russian Sovereign Debt Crisis as a placebo sample. Russia's sovereign default in August 1998 led to capital outflow from Hungary and mild economic slowdown. Figure A.5 shows that reestimating (2) on the 1995-2001 sample yields estimates that are close to zero and insignificant for all years. While local exposure to business cycle risk can change over time, these tests supports the view that the baseline results are not driven by higher cyclicality in more exposed areas.

A related concern is that $s_{z 08}^{F C}$ is correlated with lower credit quality, so that exposed areas would have seen higher defaults and a worse recession even without exposure to FC debt. While our main analysis controls for several credit quality measures, Table A.7 presents several additional checks. Column 2 shows that the results are robust to controlling for the local unemployment rate in 2007 and the home equity share of foreign currency mortgages. Anecdotal evidence suggests mis-selling of foreign currency loans was most prevalent for home equity loans (Bethlendi 2015), and a higher presence of home equity loans indeed predicts a higher default rate. In column 3 we instead instrument $s_{z 08}^{F C}$ with the FC debt share for mortgage loans, exploiting only variation in FC exposure driven by mortgage loans. Because credit quality deterioration was more severe for foreign currency home equity loans, the mortgage FC debt share is uncorrelated with 2007 household income and education (see online Appendix Table A.3). The instrumental variable estimates in column 3 are similar to the baseline estimates.

Foreign currency borrowers generally borrowed later in the credit expansion, so a related concern is that credit quality deteriorated during the boom. Table A.7 column 4 instruments the overall FC debt share with the FC debt share using only loans originated in years 2003 through 2005. The estimates using this instrument are similar to the baseline for all three outcome variables.

Credit booms, high household debt, and credit supply cycles are closely related. One may therefore wonder whether high household FC exposure areas simultaneously experienced a boom and reversal in credit supply to firms and households. The forint depreciation was associated with a large capital outflow that depressed overall credit supply. Concerns about a large-scale withdrawal of foreign credit from emerging Europe led to the Vienna Initiative, launched in February 2009. Through the Vienna Initiative, western European banks agreed to maintain specific levels of exposure to emerging Europe and to recapitalize their subsidiaries in the region, mitigating a disruptive withdrawal of credit.

In Section VA we discuss the role of credit supply to firms in more detail. Disentangling the direct effect of the increase in household debt from a credit supply shock to households is challenging, and the estimates likely capture a combination of these factors. The increase in debt burdens and the deterioration of the local economy would likely depress credit demand in exposed regions, but it would also reduce household creditworthiness. Column 5 in online Appendix Table A.7 presents a test that attempts to control for credit supply to households. The test 
is based on the intuition that credit supply expansions often mean-revert, so the overall expansion in credit may serve as a proxy for the subsequent contraction in credit supply to households. Column 5 shows that the estimates are slightly smaller compared to the baseline when controlling for the overall expansion in household debt-to-income from 2004 to 2008. Column 6 goes a step further and explicitly controls for new housing lending in the crisis. Of course, the decline in lending may stem in part from the FC debt shock, so this specification likely "over-controls." Nevertheless, the effect of household FC debt exposure remains robust.

Finally, to account for other potential shocks operating at a broad regional level, column 7 of online Appendix Table A.7 includes tighter region fixed effects for 20 major regions (NUTS-3) interacted with the Post $t_{t}$ dummy. The estimates remain highly significant, albeit smaller, which is likely because exploiting variation within NUTS-3 regions absorbs some local labor market level variation.

Measurement of the Shock.-Our results are robust to measuring household FC debt exposure using the fraction of loans in FC (column 8 of Table A.7) and the number of FC loans relative to the working-age population (column 9). The latter measure ensures that the results are not spuriously driven by settlements with a small number of loans but a high FC debt share. Column 10 reports a substantially smaller and insignificant effect using the number of local currency loans per adult.

Online Appendix Table A.9 explores an alternative to the continuous exposure measure by defining "treated" settlements as those in the top quartile of $s_{z 08}^{F C}$ and "control" settlements as those in the bottom quartile. For example, relative to "control" areas, "treated" areas see a 0.35 percentage points rise in the unemployment rate (columns 1 and 2). Columns 3 and 4 present the same analysis on a sub-sample of propensity-score-matched settlements to ensure that the distribution of covariates in treatment and control areas have common support. ${ }^{23}$ The estimates are broadly similar using the propensity-score-matched sample. Columns 5 and 6 replace the binary treatment variable with the continuous measure of exposure, $s_{z 08}^{F C}$, and reestimate the baseline specification on the matched sample. The magnitudes of the estimates on this sample are, in some cases, smaller than the baseline, but the effects remain highly significant.

Weights, Heterogeneity by City Size, and Aggregation.-Our baseline estimation weights settlements by their population in 2007. Online Appendix Table A.10 shows that the estimates fall by one-third to one-half when weighting settlements equally (column 1). This is because the effect is stronger among larger settlements, which are more closed economies and therefore subject to less local demand "leakage" (columns 2 through 4). Table A.10 also shows that the results are robust to aggregating our data up to 175 subregions that correspond to commuting zones (Pálóczi et al. 2016). ${ }^{24}$ The point estimates are slightly larger using this higher level of aggregation (columns 5 and 6).

\footnotetext{
${ }^{23}$ Online Appendix Table A.8 shows that the matched settlements are similar on key observables such as debt-to-income, income, and education.

${ }^{24}$ According to the 2001 census, 70 percent of households in Hungary live and work in the same settlement.
} 


\section{Mechanisms}

Why does the household debt revaluation translate into a large and persistent rise in local unemployment? This section presents additional evidence on the role of a local demand channel, labor market frictions, and housing market distress in explaining the worse local recession.

\section{A. Local Demand}

Theory predicts that the household debt revaluation depresses real activity through a decline in household demand. Debt revaluation should, therefore, more strongly affect firms catering to local markets (Mian and Sufi 2014b). To provide further evidence for a local household demand channel, we draw on firm-level census data to test whether the debt revaluation shock leads to a stronger decline in employment at nonexporting firms relative to exporting firms.

Table 6 displays estimates of the effect of household FC debt exposure on firm-level log employment. We estimate the following specification:

$$
\ln \left(E_{i t}\right)=\alpha_{i}+\gamma_{t}+\beta\left(s_{z 08}^{F C} \times \text { Post }_{t}\right)+\left(X_{i z} \times \text { Post }_{t}\right) \Gamma+\epsilon_{i t},
$$

where $\alpha_{i}$ is a firm fixed effect, $\gamma_{t}$ is a year fixed effect, and $X_{i z}$ represents firm and settlement-level controls. In Table 6 column 1, we find that firms in settlements with greater exposure to the household debt revaluation experience a significant decline in employment. Column 2 shows that the elasticity is similar but more precisely estimated when including firm-level controls, settlement-level controls, and fixed effects for major regions, all interacted with Post $t_{t}$. Firm-level controls are a firm's own FC debt share in 2007, a quadratic in 2007 log employment, 2007 log sales, 2007 leverage, indicator variables for whether the firm is majority state or foreign-owned, and two-digit industry fixed effects. Two-digit industry fixed effects interacted with Post $_{t}$ ensure that the estimate is not driven by time-varying industry-specific employment shocks. ${ }^{25}$

Columns 3 and 4 of Table 6 report estimates separately for nonexporters and exporters. The decline in employment and output is driven entirely by nonexporting firms. Relative to a settlement with no FC debt, nonexporting firms in a settlement with all debt in FC experience a 10.6 percent greater decline in employment. In contrast, employment at exporting firms is largely shielded from the variation in local demand induced by the debt revaluation. This test provides evidence that the effect of household debt revaluation on employment is not spuriously driven by the exchange rate channel or another shock to exporters. It also suggests that real

\footnotetext{
${ }^{25}$ The online Appendix presents several robustness tests for these firm-level employment results. Panel A in online Appendix Table A.11 shows that results are similar when controlling for firm-level lagged employment growth, ensuring that the estimates are not driven by trends in firm employment. The baseline estimates weight firms equally, but panel B shows that results are robust to weighting firms by their log employment in 2007. Table A.12 shows results are robust to using the household debt revaluation to income shock instead of the FC debt share. To address the concern that the firm-level estimates are driven by a differential contraction in bank lending to firms, online Appendix Table A.13 explicitly controls for time-varying bank lending shocks and find similar estimates on the effect of household FC debt exposure. It is also worth noting that banks operating in Hungary did not have currency mismatch on their own balance sheets, and Hungary did not experience a severe banking crisis.
} 
Table 6-Impact of Household Debt Revaluation on Firm Employment

\begin{tabular}{lccccc}
\hline \hline & \multicolumn{2}{c}{ All firms } & Nonexporters & Exporters & Nontradable \\
\cline { 2 - 3 } & $(1)$ & $(2)$ & $(3)$ & $(4)$ & $(5)$ \\
\hline HH FC debt share, $s_{z 08}^{F C} \times$ post & -8.28 & -9.78 & -10.6 & -1.35 & -11.1 \\
& $(3.04)$ & $(2.77)$ & $(3.01)$ & $(7.16)$ & $(4.76)$ \\
Firm and year fixed effects & Yes & Yes & Yes & Yes & Yes \\
Firm controls & & Yes & Yes & Yes & Yes \\
Settlement controls & & Yes & Yes & Yes & Yes \\
$R^{2}$ & & & & & 0.062 \\
Number of firms & 0.0092 & 0.071 & 0.078 & 0.081 \\
Observations & 66,267 & 66,267 & 53,336 & 12,931 & 16,761 \\
& 463,869 & 463,869 & 373,352 & 90,517 & 117,327 \\
\hline
\end{tabular}

Notes: This table presents estimates of equation (6) for the firm-level panel dataset. Firm controls are the firm FC debt share in 2007, log firm sales in 2007, leverage (debt-to-sales) in 2007, a quadratic in log firm employment in 2007 , indicator variables for whether a firm is majority state-owned or foreign-owned, and two-digit NACE industry fixed effects. Settlement controls refer to the Baseline controls, Credit quality controls, and Region fixed effects in Table 4. All controls are interacted with the Post $t_{t}$ indicator. Export status is defined as whether a firm has positive export revenues in 2007. Nontradable firms are defined as nonexporting firms in the restaurant and retail industries and four-digit NACE industries with a geographic Herfindahl index below the median, following Harasztosi and Lindner's (2019) implementation of the Mian and Sufi (2014b) classification for Hungary. Standard errors are clustered at the subregion level (175 units).

rigidities may inhibit a reallocation of labor toward exporting firms. The fact that exporters do not differentially expand employment, despite the large depreciation, suggests that there is limited adjustment through "exporting out of the downturn" in the short run. Finally, column 5 shows that focusing on firms in nontradable industries yields similar estimate as the overall decline for nonexporters.

\section{B. Limited Labor Market Adjustment}

We find suggestive evidence that the persistent rise in local unemployment is driven by limited labor market adjustment following the household debt revaluation shock. Online Appendix Table A.14 presents evidence showing that there is limited downward adjustment in wages following the depreciation, despite the increase in local unemployment (columns 1-4). These results are consistent with downward nominal wage rigidity generating persistently higher unemployment following a negative demand shock, as in Schmitt-Grohé and Uribe (2016). We also find no evidence of an increase in net out-migration from settlements with higher FC debt exposure following the depreciation (columns 5 and 6). The lack of adjustment through migration accords with recent studies that find limited adjustment to local labor market shocks through interregional migration in the short run (e.g., Autor, Dorn, and Hanson 2013).

\section{House Prices and Housing Market Distress}

A shock to debt burdens can depress house prices. Lower house prices, in turn, may amplify the downturn by reducing housing equity and limiting access to new borrowing. Figure 7 examines the dynamic effect of FC debt exposure on subregional house prices, and online Appendix Table A.15 presents the corresponding regression estimates. Our dataset contains median subregional home sale prices 


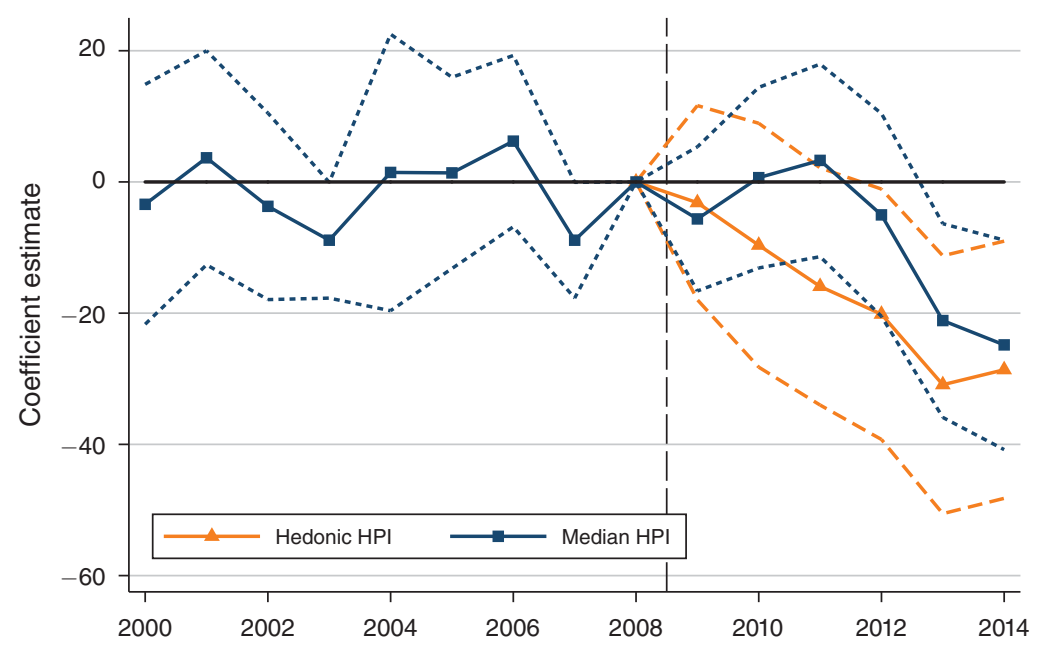

Figure 7. Household Foreign Currency Debt Exposure and House Prices

Notes: This figure presents results from estimating (2) for the log median or hedonic home price index. The hedonic home price index is available starting in 2008. The specification includes controls as in column 3 of Table 4. See online Appendix Figure A.4 for the estimates without controls. Observations are weighted by 2007 population. Dashed line represent 95 percent confidence intervals computed from standard errors clustered at the subregion level.

going back to 2000 and hedonic house price indices (HPI) starting in 2008. Both the median and hedonic HPI estimates show a gradual and persistent decline in house prices in high exposure areas after the depreciation. The estimates imply that by 2012, the debt revaluation depressed house prices by 13 percent in a settlement at the mean of FC debt exposure.

The household debt revaluation channel and housing market dynamics are closely related. However, one concern is that the estimated effects of the household debt revaluation are instead driven by a housing market cycle, for instance, through a bubble and bust in house prices or a construction boom that results in an excess supply of housing. The median HPI estimates in Figure 7 reveal that pre-trends are approximately parallel prior to the depreciation and the decline in house prices following the depreciation is gradual. Unlike many other countries Hungary did not experience a major house price boom in the years leading up to the crisis (see online Appendix Figure A.2). Columns 5-6 of online Appendix Table A.15 also show that there is no evidence of a crash in housing construction in areas with more exposure to household FC debt. To summarize, the household debt revaluation appears to depress local house prices. But the worse recession in high $s_{z 08}^{F C}$ regions is unlikely to be driven by a bubble and bust in house prices or a housing supply overhang.

\section{Financial Spillovers}

The household debt revaluation causes a more severe local recession and a fall in house prices. Thus, in addition to the direct effect on FC borrowers, the shock may negatively affect other nearby households indirectly through its negative impact on the local economy. Table 7 uses loan-level data on individual FC debt positions 
Table 7-Financial Seillovers: Loan-Level Evidence from Defaults

\begin{tabular}{lcccc}
\hline \hline & \multicolumn{2}{l}{ LC and FC housing loans } & LC borrowers & FC borrowers \\
\cline { 2 - 3 } & $(1)$ & $(2)$ & $(3)$ & $(4)$ \\
\hline$F C_{i} \times$ post & 4.03 & 3.99 & & \\
$s_{z,-b, 08}^{F C} \times$ post & $(0.21)$ & $(0.22)$ & & \\
Loan and time fixed effects & & 3.99 & 1.93 & 5.52 \\
Loan and borrower controls & & $(0.75)$ & $(0.83)$ & $(0.99)$ \\
Settlement controls & Yes & Yes & Yes & Yes \\
$R^{2}$ & Yes & Yes & Yes & Yes \\
Number of loans & 0.037 & 0.037 & Yes & Yes \\
Observations & 664,659 & 664,659 & 0.050 & 0.038 \\
& $20,960,622$ & $20,960,622$ & $7,501,797$ & $13,458,825$ \\
\hline
\end{tabular}

Notes: This table presents loan-level estimates of equation (7). The dependent variable is an indicator for whether a loan is in default in quarter $t . F C_{i}$ is an indicator that equals 1 for loans in foreign currency. $s_{z,-b, 08}^{F C}$ is the household foreign currency debt share in the borrower's settlement of residence, excluding debt owed by borrower $b$. Columns 1 and 2 present estimates for both local and foreign currency borrowers. Columns 3 and 4 split the sample into local and foreign currency borrowers. Local currency borrowers are defined as borrowers who have no individual exposure to FC debt. Loan controls refer to loan type fixed effect (mortgage or HE). Borrower controls are the total number of mortgage and HE loans, log total borrower debt in 2008:III, and five-year age bin fixed effects. Settlement controls refers to all the controls in column 3 of Table 4 . All controls are interacted with the post indicator. Standard errors are clustered at the subregion level (175 units).

to separately estimate the direct and spillover effects of the debt revaluation on defaults. We estimate loan-level default models of the form

$$
\text { Default }_{i b z t}=\alpha_{i}+\gamma_{t}+\beta_{1}\left(F C_{i} \times \text { Post }_{t}\right)+\beta_{2}\left(s_{z,-b, 08}^{F C} \times \text { Post }_{t}\right)+\epsilon_{i b z t},
$$

where Default ${ }_{i b z t}$ in an indicator for whether loan $i$ is in default at time $t, F C_{i}$ is an indicator that equals 1 if the loan is in foreign currency, and $s_{z,-b, 08}^{F C}$ is settlement $z$ 's FC debt share excluding borrower $b$ 's debt.

Column 1 in Table 7 reveals that FC loans on average have a 4.0 percentage point higher probability of default than LC loans after the depreciation. ${ }^{26}$ Column 2 includes the overall settlement FC debt share, excluding the borrower's own debt, $s_{z,-b, 08}^{F C}$, and shows that a borrower is more likely to default if many nearby households have FC debt. This estimate is consistent with local financial spillovers through the negative effect of FC debt on the local economy. The estimate implies that a borrower residing in a settlement at the mean level of local FC debt exposure is 2.6 percentage points more likely to default, conditional on her own foreign currency debt position, relative to a borrower in a settlement with zero local FC debt exposure. ${ }^{27}$

Columns 5 and 6 split the sample of loans by borrowers who only have LC debt and borrowers who have at least one FC loan. Local exposure to the household debt revaluation predicts a higher probability of default for both LC and FC borrowers.

\footnotetext{
${ }^{26}$ Online Appendix Table A.16 shows that the impact of FC exposure on default is stronger for borrowers with higher leverage and shorter maturity loans, consistent with the importance of liquidity constraints.

${ }^{27}$ Gupta (2016) shows evidence of foreclosure spillovers through an information channel or peer effects. The spillovers in Gupta (2016) dissipate beyond a 0.1 mile radius and therefore do not appear to be driven by a local demand externality. Huber (2018) presents evidence that bank lending contractions can have negative spillover affects on other local firms through negative demand spillovers.
} 
Panel A. Local currency borrowers

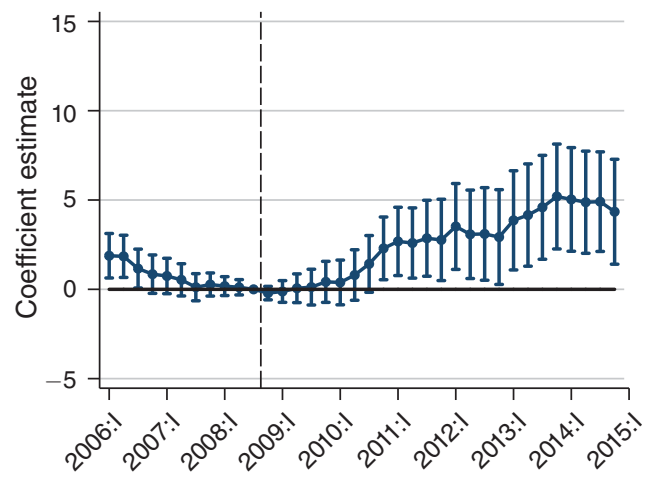

Panel B. Foreign currency borrowers

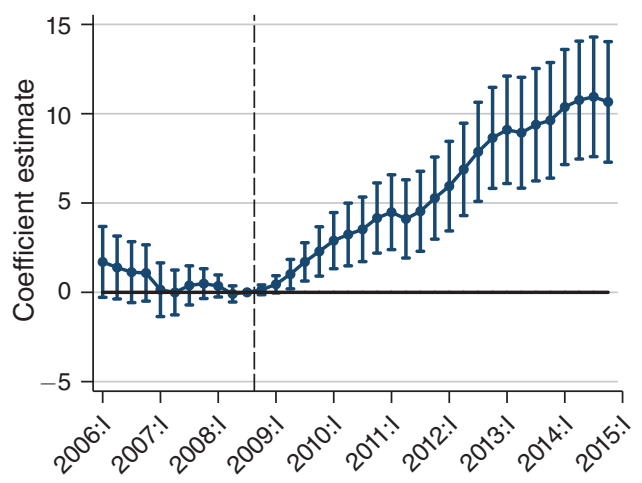

Figure 8. Financial Spillovers over Time

Notes: This figure presents estimates of $\left\{\beta_{q}\right\}$ from

$$
\text { Default }_{i b z t}=\alpha_{i}+\gamma_{t}+\sum_{q \neq 2008: \mathrm{III}} \beta_{q}\left(\mathbf{1}_{t=q} \cdot s_{z,-b, 08}^{F C}\right)+\sum_{q \neq 2008: \mathrm{III}}\left(\mathbf{1}_{t=q} \cdot X_{i b z}\right) \Gamma_{q}+\epsilon_{i b z t},
$$

where the dependent variable is an indicator for whether loan $i$, held by borrower $b$, residing in settlement $z$ is in default at time $t$. The specification is estimated separately for local and foreign currency borrowers. Controls in $X_{i b z}$ are as in Table 7. Error bars represent 95 percent confidence intervals computed from standard errors clustered at the subregion level.

The effect on LC borrowers in column 5 suggests that borrowing in FC imposes negative spillovers on individuals without FC debt. Nevertheless, the spillover effect is stronger for FC borrowers. FC borrowers are presumably more sensitive to local shocks because the exchange rate depreciation simultaneously impairs their own balance sheets. Figure 8 shows the dynamic effect of local FC debt exposure on LC and FC borrowers, showing that the spillover effect is highly persistent. There is, however, evidence that high $s_{z,-b, 08}^{F C}$ areas display a relative decline in default rates prior to the depreciation.

Finally, it is worth noting that when we include $s_{z,-b, 08}^{F C} \times$ Post in the estimating equation, the estimate of $\beta_{1}$ declines by a modest amount from 4.03 in column 1 to 3.99 in column 2. As we show formally using a simple statistical model in online Appendix Section E, the small decline in the coefficient suggests that local-level selection on unobservables must be small. The reason is that local-level unobserved selection would be captured in $s_{z,-b, 08}^{F C}$. Therefore, if an unobserved local-level variable that affects both $F C_{i}$ and default were an important component of the variation in $F C_{i}$, the estimate of $\beta_{1}$ would decline substantially when controlling for $s_{z,-b, 08}^{F C}$. This small decline in the estimate of $\beta_{1}$ is reassuring, as it also suggests that omitted variable bias in the estimate of $\beta_{2}$ is limited.

\section{Household and Firm Foreign Currency Debt}

Since the Latin American and East Asian crises of the 1990s, several studies have found that firm $\mathrm{FC}$ indebtedness leads to a fall in investment after a devaluation. Prior to the forint depreciation in late 2008, 48 percent of Hungarian nonfinancial firm debt was denominated in FC. This raises two questions. First, are the determinants 
Table 8-Firm FC Debt, Household FC Debt, and Firm-Level Outcomes

\begin{tabular}{lccccc}
\hline \hline & $\begin{array}{c}\text { log } \\
\text { investment } \\
(1)\end{array}$ & $\begin{array}{c}\text { Investment/ } \\
\text { capital } \\
(2)\end{array}$ & $\begin{array}{c}\text { log } \\
\text { sales } \\
(3)\end{array}$ & $\begin{array}{c}\text { log real } \\
\text { value added } \\
(4)\end{array}$ & $\begin{array}{c}\text { log } \\
\text { employment } \\
(5)\end{array}$ \\
\hline Firm FC debt share $\times$ post & -38.5 & -16.6 & 9.91 & 10.2 & 4.21 \\
& $(2.44)$ & $(1.31)$ & $(1.14)$ & $(1.10)$ & $(0.49)$ \\
HH FC debt share, $s_{z 08}^{F C} \times$ post & -32.9 & 3.68 & -14.3 & -18.9 & -9.38 \\
& $(16.7)$ & $(4.06)$ & $(7.42)$ & $(7.70)$ & $(2.82)$ \\
Firm and year fixed effects & Yes & Yes & Yes & Yes & Yes \\
Firm controls & Yes & Yes & Yes & Yes & Yes \\
Settlement controls & Yes & Yes & Yes & Yes & Yes \\
$R^{2}$ & 0.052 & 0.047 & 0.037 & 0.064 & 0.067 \\
Number of firms & 66,263 & 66,267 & 66,267 & 66,259 & 66,267 \\
Observations & 418,239 & 463,869 & 463,869 & 461,860 & 463,869 \\
\hline
\end{tabular}

Notes: This table presents firm-level regressions comparing the effects of local household FC debt and firm FC debt on the evolution of firm outcomes around the late-2008 forint depreciation. The dependent variables are log investment (column 1), the investment-to-lagged capital ratio (column 2), log firm sales (column 3), log firm real value added (column 4), and log firm employment (columns 5). Both FC debt share is measured in 2008. The number of observations in column 1 is lower than in column 2, as investment can be negative in the NAV data. Investment-to-capital is winsorized at the fifth and ninety-fifth percentiles due to outliers caused by very low levels of measured capital. Firm controls are as in Table 6, but we also control for firm export status. Settlement controls refer to the Baseline controls, Region fixed effects, and Credit quality controls. All controls are interacted with Post $t_{t}$. Standard errors are clustered at the subregion level (175 units).

of FC borrowing similar for households and firms? Second, in a currency crisis, does it matter whether it is households or firms that have FC debt exposure?

Unlike households, in this setting, firms with FC debt are strongly positively selected. Online Appendix Table A.17 shows that firms with FC debt are larger, more productive, and more likely to be exporters. Moreover, three-fourths of firm FC debt is in euro, which corresponds to the primary invoicing currency for exports. In contrast, 97 percent of household FC debt is in Swiss franc, but household income and assets in Swiss franc are negligible. These differences in the determinants of household and firm FC borrowing explain why household and firm FC debt shares are uncorrelated across space, as we saw in Table 3. Table A.18 confirms that this holds across the firm size distribution. This implies that the contractionary effect of the household debt revaluation channel is not explained by firm FC debt.

Do firm balance sheet effects play a complementary role in the currency crisis? Table 8 presents regressions similar to equation (6) for various firm-level outcomes on a firm's FC debt share and the local household FC debt share. Columns 1 and 2 reveal that firms with a higher fraction of debt denominated in FC reduce their investment after the depreciation. However, columns 3 through 5 show that firms with FC debt experience stronger growth in sales, value added, and employment. ${ }^{28}$ One explanation for why firms with FC debt exposure do not experience declines in sales and employment is that these firms are more productive and have better growth

\footnotetext{
${ }^{28}$ Online Appendix Table A.19 decomposes firm FC debt exposure in Swiss franc and euro debt. The forint depreciated substantially more against the Swiss franc than the euro. Compared to firms with euro debt, firms with Swiss franc debt performed worse in the crisis. However, even firms with Swiss franc debt do not perform worse than firms without FC debt on all outcomes except for investment.
} 
opportunities. These firms therefore temporarily cut back on investment following a balance-sheet shock, but retain their employees in anticipation of stronger growth in the future. ${ }^{29}$ Household FC debt exposure, meanwhile, predicts a decline in all firm outcomes.

\section{Conclusion}

Foreign currency lending to households was widespread in Europe prior to the 2008 financial crisis. This led to severe increases in debt burdens when domestic currencies depreciated sharply against funding currencies including the Swiss franc. Using data at the household and local level from Hungary, we trace the effects of a sudden, large-scale revaluation of household foreign currency debt burdens on household defaults, durable spending, and local economic activity.

We find that a revaluation in household debt burdens increases household financial distress and sharply reduces local consumption, employment, and house prices. Employment losses are driven by firms reliant on local demand. The estimates imply that a $\$ 29,000$ (2008 PPP) increase in annual debt service destroys one job-year. This translates into a peak cross-sectional output multiplier on debt service of 1.67 after two years. In addition, we find negative spillover effects of local household foreign currency debt on nearby borrowers without foreign currency debt. Our results are broadly consistent with recent models emphasizing demand and pecuniary externalities of foreign currency financing.

Our results have several interesting policy implications. First, we provide an empirical rationale for macroprudential policies to limit leverage. The case for prudential policy is particularly strong for risky financing, such as foreign currency borrowing by agents without a natural hedge against exchange rate risk. Second, our results imply that monetary policy faces a dilemma in a crisis in economies with foreign currency debt. When foreign currency leverage is high, it becomes counterproductive to stimulate external demand by depreciating the exchange rate because a weaker exchange rate deteriorates private-sector balance sheets. By using information on the foreign currency exposures of both households and firms, our results indicate that the debt revaluation channel is particularly strong when households have foreign currency debt.

While we point to a clear role for household foreign currency debt in depressing real activity, our analysis contains several limitations. Our analysis relies on variation in exposure to household foreign currency debt and assumes that, conditional on a rich set of controls, that exposure is not correlated with other business cycle shocks. Although differential pretrends are limited, more exposed areas do experience a relative boom in some outcomes. Moreover, our methodology is unable to fully disentangle the roles of a decline in household demand and a contraction in credit supply to households in the transmission of the debt revaluation. Finally, our analysis relies on cross-sectional variation, so we cannot capture the equilibrium effect of

\footnotetext{
${ }^{29}$ Salomao and Varela (2016) also finds that firms with foreign currency debt had stronger sales growth and did not have higher exit rates following the exchange rate depreciation. Salomao and Varela (2016) presents a model in which more productive firms select into cheaper but riskier FC financing to grow more quickly.
} 
the debt revaluation on the exchange rate, which may be an important amplification mechanism. We look forward to future work addressing these questions.

\section{REFERENCES}

- Agarwal, Sumit, Gene Amronin, Itzhak Ben-David, Souphala Chomsisengphet, Tomasz Piskorski, and Amit Seru. 2017. "Policy Intervention in Debt Renegotiation: Evidence from the Home Affordable Modification Program.” Journal of Political Economy 125 (3): 654-712.

-Aguiar, Mark. 2005. "Investment, Devaluation, and Foreign Currency Exposure: The Case of Mexico." Journal of Development Economics 78 (1): 95-113.

Auclert, Adrien. 2016. "Monetary Policy and the Redistribution Channel." Unpublished.

Auclert, Adrien, Will Dobbie, and Paul Goldsmith-Pinkham. 2019. "Macroeconomic Effects of Debt Relief: Consumer Bankruptcy Protections in the Great Recession." Unpublished.

- Autor, David H., David Dorn, and Gordon H. Hanson. 2013. "The China Syndrome: Local Labor Market Effects of Import Competition in the United States." American Economic Review 103 (6): 2121-68.

- Backus, David K., and Gregor W. Smith. 1993. "Consumption and Real Exchange Rates in Dynamic Economies with Non-Traded Goods.” Journal of International Economics 35 (3-4): 297-316.

Banai, Ádám, Júlia Király, and Márton Nagy. 2011. "The Demise of the Halcyon Days in Hungary: 'Foreign' and 'Local' Banks: Before and After the Crisis." In BIS Papers, Vol. 54: The Global Crisis and Financial Intermediation in Emerging Market Economies, 195-224. Basel, Switzerland: BIS.

- Beer, Christian, Steven Ongena, and Marcel Peter. 2010. "Borrowing in Foreign Currency: Austrian Households as Carry Traders." Journal of Banking \& Finance 34 (9): 2198-2211.

Bernanke, Ben, and Mark Gertler. 1989. "Agency Costs, Net Worth, and Business Fluctuations." American Economic Review 79 (1): 14-31.

Bethlendi, András. 2015. "Bad Product Development Results in Systemic Market Failure: Foreign Currency Mortgage Loans to Hungarian Households." Financial and Economic Review 14 (1): 5-30.

BIS. 2019. "BIS Credit to the Non-financial Sector Database." (Accessed March 2016).

-Bleakley, Hoyt, and Kevin Cowan. 2008. "Corporate Dollar Debt and Depreciations: Much Ado about Nothing?" Review of Economics and Statistics 90 (4): 612-26.

Caballero, Ricardo J., and Arvind Krishnamurthy. 2003. "Excessive Dollar Debt: Financial Development and Underinsurance." Journal of Finance 58 (2): 867-93.

Calvo, Guillermo A., Alejandro Izquierdo, and Luis-Fernando Mejía. 2008. "Systemic Sudden Stops: The Relevance of Balance-Sheet Effects and Financial Integration.” NBER Working Paper 14026.

- Carroll, Christopher D. 2001. "A Theory of the Consumption Function, with and without Liquidity Constraints." Journal of Economic Perspectives 15 (3): 23-45.

- Chari, V. V., Patrick J. Kehoe, and Ellen R. McGrattan. 2005. "Sudden Stops and Output Drops." American Economic Review 95 (2): 381-87.

-Chodorow-Reich, Gabriel. 2019. "Geographic Cross-Sectional Fiscal Spending Multipliers: What Have We Learned?" American Economic Journal: Economic Policy 11 (2): 1-34.

Company Information Office (CIO). 2017. "Firm Establishment Addresses." Company Information Office (accessed April 2017).

de Ferra, Sergio, Kurt Mitman, and Federica Romei. 2019. "Household Heterogeneity and the Transmission of Foreign Shocks." Unpublished.

Devereux, Michael B., and Gregor W. Smith. 2007. "Transfer Problem Dynamics: Macroeconomics of the Franco-Prussian War Indemnity." Journal of Monetary Economics 54 (8): 2375-98.

Di Maggio, Marco, and Amir Kermani. 2017. "Credit-Induced Boom and Bust." Review of Financial Studies 30 (11): 3711-58.

Di Maggio, Marco, Amir Kermani, Benjamin J. Keys, Tomasz Piskorski, Rodney Ramcharan, Amit Seru, and Vincent Yao. 2017. "Interest Rate Pass-Through: Mortgage Rates, Household Consumption, and Voluntary Deleveraging." American Economic Review 107 (11): 3550-88.

Donaldson, Jason Roderick, Giorgia Piacentino, and Anjan V. Thakor. 2016. "Household Debt and Unemployment." Unpublished.

Du, Wenxin, and Jesse Schreger. 2015. "Sovereign Risk, Currency Risk, and Corporate Balance Sheets." Unpublished.

Dynan, Karen. 2012. "Is a Household Debt Overhang Holding Back Consumption?" Brookings Papers on Economic Activity (Spring): 299-344.

-Eggertsson, Gauti B., and Paul Krugman. 2012. "Debt, Deleveraging, and the Liquidity Trap: A Fisher-Minsky-Koo Approach." Quarterly Journal of Economics 127 (3): 1469-1513. 
Eichengreen, Barry, and Ricardo Hausman, eds. 2005. Other People's Money: Debt Denomination and Financial Instability in Emerging Market Economies. Chicago: University of Chicago Press.

-Farhi, Emmanuel, and Iván Werning. 2016. "A Theory of Macroprudential Policies in the Presence of Nominal Rigidities.” Econometrica 84 (5): 1645-1704.

Fidrmuc, Jarko, Mariya Hake, and Helmut Stix. 2013. "Households' Foreign Currency Borrowing in Central and Eastern Europe." Journal of Banking \& Finance 37 (6): 1880-97.

-Fisher, Irving. 1933. "The Debt-Deflation Theory of Great Depressions." Econometrica 1 (4): 337-57.

Gál, Zoltán. 2005. "The Development and the Polarised Spatial Structure of the Hungarian Banking System in a Transforming Economy." In Hungarian Spaces and Places: Patterns of Transition, edited by Györgyi Barta et al., 197-219. Pécs, Hungary: Centre for Regional Studies.

-Galí, Jordi, and Tommaso Monacelli. 2005. "Monetary Policy and Exchange Rate Volatility in a Small Open Economy." Review of Economic Studies 72 (3): 707-34.

Ganong, Peter, and Pascal Noel. 2019. "The Effect of Debt on Default and Consumption: Evidence from Housing Policy in the Great Recession." Unpublished.

Gupta, Arpit. 2016. "Foreclosure Contagion and the Neighborhood Spillover Effects of Mortgage Defaults." Unpublished.

Gyöngyösi, Gyózô, and Emil Verner. 2019. "Financial Crisis, Creditor-Debtor Conflict, and Political Extremism." Unpublished.

Hall, Robert E. 1978. "Stochastic Implications of the Life Cycle-Permanent Income Hypothesis: Theory and Evidence." Journal of Political Economy 86 (6): 971-87.

-Harasztosi, Peter, and Attila Lindner. 2019. "Who Pays for the Minimum Wage?" American Economic Review 109 (8): 2693-2727.

Huber, Kilian. 2018. "Disentangling the Effects of a Banking Crisis: Evidence from German Firms and Counties.” American Economic Review 108 (3): 868-98.

Huo, Zhen, and José-Víctor Ríos-Rull. 2016. "Financial Frictions, Asset Prices, and the Great Recession." Unpublished.

Ibragimov, Rustam, and Ulrich K. Müller. 2016. "Inference with Few Heterogeneous Clusters." Review of Economics and Statistics 98 (1): 83-96.

-Ilzetzki, Ethan, Carmen M. Reinhart, and Kenneth S. Rogoff. 2019. "Exchange Arrangements Entering the Twenty-First Century: Which Anchor will Hold?" Quarterly Journal of Economics 134 (2): 599-646.

International Financial Statistics (IFS). 2016. "IMF International Financial Statistics." International Financial Statistics (accessed March 2016).

International Monetary Fund (IMF). 2003. “Argentina: 2002 Article IV Consultation.” IMF Country Report 03/226.

International Monetary Fund (IMF). 2011. "Hungary: 2010 Article IV Consultation.” IMF Country Report 11/35.

Jordà, Òscar, Moritz Schularick, and Alan M. Taylor. 2014. "The Great Mortgaging: Housing Finance, Crises, and Business Cycles.” NBER Working Paper 20501.

Keynes, J. M. 1929. “The German Transfer Problem.” Economic Journal 39 (153): 1-7.

Kim, Yun Jung, Linda L. Tesar, and Jing Zhang. 2015. "The Impact of Foreign Liabilities on Small Firms: Firm-Level Evidence from the Korean Crisis.” Journal of International Economics 97 (2): 209-30.

- Kiyotaki, Nobuhiro, and John Moore. 1997. "Credit Cycles.” Journal of Political Economy 105 (2): $211-48$.

Korinek, Anton. 2011. "Excessive Dollar Borrowing in Emerging Markets: Balance Sheet Effects and Macroeconomic Externalities.” Unpublished.

Korinek, Anton, and Alp Simsek. 2016. "Liquidity Trap and Excessive Leverage." American Economic Review 106 (3): 699-738.

Krugman, Paul. 1999. "Balance Sheets, the Transfer Problem, and Financial Crises." International Tax and Public Finance 6: 459-72.

KSH. 2011. "Census.” Central Statistical Office (accessed June 2017).

KSH. 2016. "T-Star Database.” Central Statistical Office (accessed June 2016).

Mendoza, Enrique G. 2010. "Sudden Stops, Financial Crises, and Leverage." American Economic Review 100 (5): 1941-66.

Mian, Atif, Kamalesh Rao, and Amir Suf. 2013. "Household Balance Sheets, Consumption, and the Economic Slump.” Quarterly Journal of Economics 128 (4): 1687-1726.

Mian, Atif, and Amir Sufi. 2014a. House of Debt: How They (and You) Caused the Great Recession and How We Can Prevent It from Happening Again. Chicago: University of Chicago Press.

Mian, Atif, and Amir Sufi. 2014b. "What Explains the 2007-2009 Drop in Employment?" Econometrica 82 (6): 2197-2223. 
Mian, Atif, Amir Sufi, and Emil Verner. 2017. "Household Debt and Business Cycles Worldwide." Quarterly Journal of Economics 132 (4): 1755-1817.

- Mian, Atif, Amir Suf, and Emil Verner. 2020. "How Does Credit Supply Expansion Affect the Real Economy? The Productive Capacity and Household Demand Channels.” Journal of Finance 75 (2): 949-94.

Mishkin, Frederic S. 1978. "The Household Balance Sheet and the Great Depression.” Journal of Economic History 38 (4): 918-37.

MNB. 2016a. "Bank Level Interest Rate Database." National Bank of Hungary (accessed June 2016).

MNB. 2016b. "Firm Register of the Central Credit Information System." National Bank of Hungary (accessed June 2016).

MNB. 2016c. "Household Register of the Central Credit Information System." National Bank of Hungary (accessed June 2016).

MNB. 2017. "MNB Home Purchase Transactions Database." National Bank of Hungary (accessed June 2017).

MNB. 2018a. "Bank Level Loan-to-Value Database.” National Bank of Hungary (accessed June 2018).

MNB. 2018b. "Three-Banks Dataset.” National Bank of Hungary (accessed January 2018).

MNB. 2019. "Composition of Loans Extended to the Household Sector." MNB Financial Stability Statistics (accessed June 2016).

-Nakamura, Emi, and Jón Steinsson. 2018. "Identification in Macroeconomics." Journal of Economic Perspectives 32 (3): 59-86.

NAV. 2016. "Corporate Income Tax Returns Database." National Tax and Customs Administration (accessed June 2016).

OeNB. 2018. “OeNB Euro Survey.” National Bank of Austria (accessed April 2018).

Doster, Emily. 2019. "Unobservable Selection and Coefficient Stability: Theory and Evidence.” Journal of Business \& Economic Statistics 37 (2): 187-204.

Pálóczi, Gábor, János Pénzes, Pavol Hurbánek, Marián Halás, and Pavel Klapka. 2016. "Attempts to Delineate Functional Regions in Hungary Based on Commuting Data." Regional Statistics 6 (1): 23-41.

Pellényi, Gábor, and Péter Bilek. 2009. "Foreign Currency Borrowing: The Case of Hungary." FINESS Working Paper D.5.4.

Ramey, Valerie A. 2016. "Macroeconomic Shocks and Their Propagation." In Handbook of Macroeconomics, Vol. 2, edited by John B. Taylor and Harald Uhlig, 71-162. Amsterdam: Elsevier.

Ranciere, Romain, Aaron Tornell, and Athanasios Vamvakidis. 2010. "Currency Mismatch, Systemic Risk and Growth in Emerging Europe.” European Policy 25 (64): 597-658.

Rózsavölgyi, Réka, and Viktória Kovács. 2005. "Housing Subsidies in Hungary: Curse or Blessing?" ECFIN Country Focus 2 (18).

Salomao, Juliana, and Liliana Varela. 2016. "Exchange Rate Exposure and Firm Dynamics.” Unpublished.

-Schmitt-Grohé, Stephanie, and Martín Uribe. 2016. "Downward Nominal Wage Rigidity, Currency Pegs, and Involuntary Unemployment.” Journal of Political Economy 124 (5): 1466-1514.

Szigel, Gabor. 2012. "Less Known Facts about Foreign Currency Lending to Households in Hungary. Foreign Currency Lending to Households in Central and Eastern Europe." Unpublished.

TARKI. 2019. "Household Monitor.” TÁRKI Zrt (accessed June 2019).

Verner, Emil, and Gyôzó Gyöngyösi. 2020. "Replication Data for: Household Debt Revaluation and the Real Economy: Evidence from a Foreign Currency Debt Crisis.” American Economic Association [publisher], Inter-university Consortium for Political and Social Research [distributor]. https://doi. org/10.3886/E118481V1. 